\title{
Long-term immobilization of technetium via bioremediation with slow-release substrates
}

DOI:

10.1021/acs.est.6b04876

\section{Document Version}

Accepted author manuscript

Link to publication record in Manchester Research Explorer

\section{Citation for published version (APA):}

Newsome, L., Cleary, A., Morris, K., \& Lloyd, J. (2017). Long-term immobilization of technetium via bioremediation with slow-release substrates. Environmental Science and Technology, 51(3).

https://doi.org/10.1021/acs.est.6b04876

\section{Published in:}

Environmental Science and Technology

\section{Citing this paper}

Please note that where the full-text provided on Manchester Research Explorer is the Author Accepted Manuscript or Proof version this may differ from the final Published version. If citing, it is advised that you check and use the publisher's definitive version.

\section{General rights}

Copyright and moral rights for the publications made accessible in the Research Explorer are retained by the authors and/or other copyright owners and it is a condition of accessing publications that users recognise and abide by the legal requirements associated with these rights.

\section{Takedown policy}

If you believe that this document breaches copyright please refer to the University of Manchester's Takedown Procedures [http://man.ac.uk/04Y6Bo] or contact uml.scholarlycommunications@manchester.ac.uk providing relevant details, so we can investigate your claim.

\section{OPEN ACCESS}


$4{ }^{1}$ Williamson Research Centre and Research Centre for Radwaste Disposal, School of Earth, 5 Atmospheric and Environmental Sciences, Williamson Building, Oxford Road, Manchester, 6

9 Radioactively contaminated land; Groundwater; Sulfide; Zero valent iron; HRC; MRC; EHC

\section{bioremediation with slow-release substrates}

\author{
Laura Newsome ${ }^{1 *}$, Adrian Cleary ${ }^{1}$, Katherine Morris ${ }^{1}$, Jonathan R Lloyd ${ }^{1}$
}

M13 9PL, UK

* L. Newsome. Email: laura.newsome@manchester.ac.uk. Phone: +44 (0)161 2750309.

\section{8}

Radioactively contaminated land; Groundwater; Sulfide; Zero valent iron; HRC; MRC; EHC

\section{Long-term immobilization of technetium via}

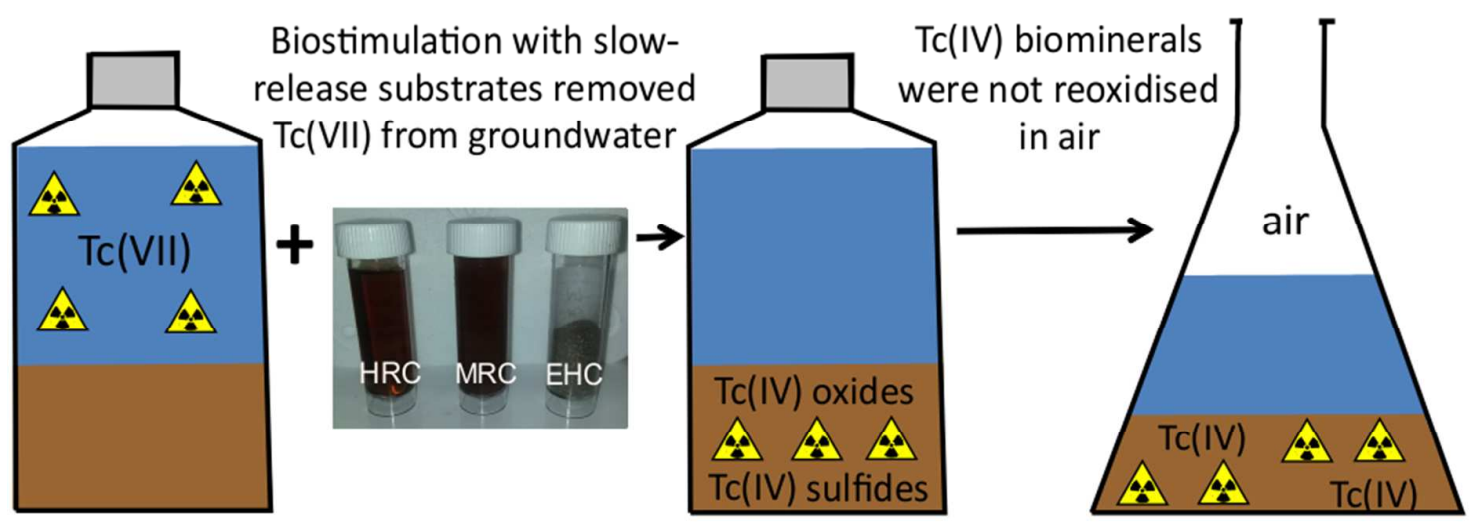


12 Radionuclides are present in groundwater at contaminated nuclear facilities with

13 technetium-99 one of the most mobile radionuclides encountered. In situ bioremediation via

14 the generation of microbially-reducing conditions has the potential to remove aqueous and

15 mobile $\mathrm{Tc}(\mathrm{VII})$ from groundwater as insoluble $\mathrm{Tc}(\mathrm{IV})$. However, questions remain regarding

16 the optimal methods of biostimulation and the stability of reduced Tc(IV) phases under oxic

17 conditions. Here, we selected a range of slow-release electron donor / chemical reduction

18 based substrates available for contaminated land treatment, and assessed their potential to

19 stimulate the formation of recalcitrant Tc(IV) biominerals under conditions relevant to

20 radioactively contaminated land. These included a slow-release poly-lactate substrate (HRC),

21 a similar substrate with an additional organosulfur ester (MRC) and a substrate containing

22 zero valent iron and plant matter (EHC). Results showed that Tc was removed from solution

23 in the form of poorly soluble hydrous Tc(IV)-oxides or Tc(IV)-sulfides during the

24 development of reducing conditions. Reoxidation experiments showed that these phases

25 were largely resistant to oxidative remobilisation and were more resistant than Tc(IV)

26 produced via biostimulation with an acetate/lactate electron donor mix in the sediments

27 tested. The implications of the targeted formation of recalcitrant Tc(IV) phases using these

28 proprietorial substrates in situ is discussed in the context of the long-term management of

29 technetium at legacy nuclear sites.

\section{INTRODUCTION}

Technetium is a significant contaminant at legacy nuclear facilities, including Sellafield in

the UK, the Hanford site in Washington, USA and Mayak, Russia. ${ }^{1}$ In oxygenated environments $\mathrm{Tc}(\mathrm{VII})$ is soluble and mobile as the pertechnetate ion $\left(\mathrm{TcO}_{4}{ }^{-}\right)$but under reducing conditions it precipitates as Tc(IV) species including hydrous, short-chain $\mathrm{TcO}_{2}$

35 phases $^{2-5}$ and under sulfidic conditions as $\mathrm{TcS}_{2}{ }^{6,7}$ These reductive processes can be microbially mediated and are beneficial for treating radioactive contaminants in the 
37 subsurface. ${ }^{8-12}$ Previous studies have shown that the stimulation of sediment microbial

38 communities by the addition of an electron donor can indirectly lead to the reduction of

$39 \mathrm{Tc}(\mathrm{VII})$ to poorly soluble $\mathrm{Tc}(\mathrm{IV})$ phases, via reaction with biogenic Fe(II) or sulfide. ${ }^{7,13-16}$

40 Moreover, iron(II)-containing minerals are able to reduce $\mathrm{Tc}(\mathrm{VII})$ to $\mathrm{Tc}(\mathrm{IV})$ abiotically $6,14,17$

41 or in the case of biotite and chlorite, after the minerals have been primed by reaction with

42 Fe(III)-reducing microorganisms. ${ }^{4}$ Therefore stimulating the development of microbially-

43 reducing conditions, in particular Fe(III) and sulfate reduction, shows potential for

44 remediating Tc-contaminated groundwaters.

45 Most previous Tc bioremediation studies have used electron donors in the form of simple

46 organics such as acetate or ethanol. ${ }^{18-20}$ However, stimulating the subsurface with these may

47 be unsuitable for radioactively contaminated land due to the likely need for repeated application of large volumes of liquid, which will be logistically challenging at a nuclear licensed site, and may potentially have deleterious effects on contaminant pathways and groundwater flow. In this situation, slow-release electron donors may be more appropriate;

51 typically these are viscous liquids or fine grained solids that remain in the subsurface for

52 longer periods whilst they slowly react (via corrosion or hydrolysis) or are biodegraded to

53 gradually release electron donors to solution. ${ }^{21-25}$

54 In this study we investigated a range of slow-release substrates pertinent to radionuclide bioremediation including; a slow-release electron donor to stimulate anaerobic microbial metal reduction (HRC), a slow-release electron donor with the potential to stimulate

57 sulfidation (MRC), and a slow-release substrate also containing zero-valent iron (ZVI) as a chemical reductant (EHC). ZVI has previously shown potential to remove $\mathrm{Tc}(\mathrm{VII})$ from

59 solution $^{26,27}$ and can directly reduce Tc(VII) to poorly soluble Tc(IV). ${ }^{28}$ Under anaerobic

60 conditions ZVI corrodes to generate Fe(II) and hydrogen and therefore offers a powerful

61 combination of reactants for $\mathrm{Tc}(\mathrm{VII})$ bioremediation; the $\mathrm{Fe}(0)$ and the associated corrosion 
62 products, mainly Fe(II) minerals, can reduce $\mathrm{Tc}(\mathrm{VII})$ to poorly soluble $\mathrm{Tc}(\mathrm{IV})$ abiotically and 63 the $\mathrm{H}_{2}$ may stimulate a number of beneficial microbial processes. ${ }^{29,30}$ These include: $\mathrm{H}_{2}$ 64 acting as an electron donor to generate additional Fe(II) by stimulating microbial Fe(III) 65 reduction ${ }^{31,32}$; stimulating the production of sulfide via sulfate-reducing bacteria ${ }^{33,34}$ which 66 may precipitate Tc-sulfide minerals ${ }^{7}$; and potentially should elevated Tc(VII) concentrations

67 exist, $\mathrm{H}_{2}$ may also stimulate enzymatic Tc(VII) reduction via hydrogenase enzymes. ${ }^{8,35-40}$

68 Moreover, microbially-mediated Tc(VII) removal has been observed below the predicted 69 solubility threshold for $\mathrm{TcO}_{2}$ precipitates, likely via sorption of $\mathrm{Tc}(\mathrm{IV})$ to sediment at these 70 very low concentrations. ${ }^{41,42}$

71 Microbially-reduced sediments are known to be susceptible to oxidative remobilisation of 72 redox active radionuclides ${ }^{12}$ and biogenic hydrous $\mathrm{TcO}_{2}$ is partially reoxidised after exposure 73 to air, although it is less susceptible to reoxidation from the addition of nitrate (via the 74 formation of reactive nitrite). ${ }^{16,43,44}$ It is crucial to understand the factors that may affect the 75 longevity of microbially-precipitated Tc(IV) in the subsurface in order to tailor successful 76 long-term remediation strategies. As an alternative to stimulating the formation of short-chain 77 hydrous $\mathrm{TcO}_{2}$ phases, the targeted formation of Tc-sulfides is of interest. ${ }^{6,7,26}$ Technetium 78 sulfides are poorly soluble and considered to be the solubility limiting phase for 79 technetium. ${ }^{45,46}$ Sulfide mineral phases can fix Tc(VII) through sorption and reductive 80 precipitation ${ }^{46}$ and it has been suggested that $\mathrm{TcS}_{2}$ is more resistant to oxidation compared to $81 \mathrm{TcO}_{2}$ under abiotic conditions. ${ }^{47}$ Finally, the presence of Fe may play an important role in 82 limiting $\mathrm{Tc}(\mathrm{IV})$ reoxidation as $\mathrm{Tc}(\mathrm{IV})$ associated with $\mathrm{Fe}(\mathrm{III})$ is considered more resistant to 83 reoxidation than $\mathrm{Tc}(\mathrm{IV}) \mathrm{O}_{2} \cdot \mathrm{nH}_{2} \mathrm{O} .^{3,48}$

84 The goal of these experiments was to investigate the effectiveness of slow-release electron 85 donors to remediate $\mathrm{Tc}(\mathrm{VII})$-contaminated groundwater, in particular, to assess whether they 86 could stimulate the in situ formation of recalcitrant Tc(IV) species including oxides and 
87 sulfides. The results showed that each slow-release substrate stimulated the removal of $\mathrm{Tc}_{\mathrm{aq}}$

88 from solution, and reoxidation experiments indicated that Tc was not remobilised under 89 oxidising conditions.

\section{$90 \quad$ MATERIALS AND METHODS}

91 Proprietary substrates: The electron donors selected were the proprietary substances Hydrogen Release Compound (HRC), a glycerol poly-lactate compound, and Metals Release Compound (MRC), a glycerol poly-lactate compound containing an organo-sulfur ester, both supplied by Regenesis, and EHC, a mixture of ZVI and food-grade plant matter, supplied by Peroxychem (Table S1). These are designed to be slow-release substrates suitable for sustained stimulation of microbial activity in situ, while EHC also contains ZVI, a chemical reductant. reduction experiments, initial tests were performed to assess whether the microbial community present in Sellafield sediments was able to use these electron donors to reduce $\mathrm{Fe}(\mathrm{III})$. Microcosms were set up containing $3 \mathrm{~g}$ of a gravelly sand sediment collected from a Sellafield site borehole (designed RB27 and fully described in past work) ${ }^{49}, 30 \mathrm{ml}$ of sterile artificial groundwater (containing the following in $\mathrm{mM}$ : $\mathrm{K}^{+} 0.089 ; \mathrm{Na}^{+} 3.37 ; \mathrm{Ca}^{2+} 1.69 ; \mathrm{Mg}^{2+}$ $\left.0.795 ; \mathrm{Cl}^{-} 1.06 ; \mathrm{HCO}_{3}{ }^{-} 2.88 ; \mathrm{NO}_{3}{ }^{-} 0.332 ; \mathrm{CO}_{3}{ }^{2-} 1.69 ; \mathrm{SO}_{4}{ }^{2-} 0.39\right)^{50}$ and $0.15 \mathrm{~g}$ of the slowrelease donor compound. ${ }^{51}$ The microcosm headspace was degassed with argon and the bottles were incubated in the dark at room temperature. Additional tests were conducted to determine whether $100 \mathrm{~Bq} \mathrm{ml}^{-1}(1.6 \mu \mathrm{M}){ }^{99} \mathrm{Tc}(\mathrm{VII})$ as pertechnetate was soluble in the presence of the electron donors in sediment-free systems, by adding $0.15 \mathrm{~g}$ of electron donor to $30 \mathrm{ml}$ artificial groundwater under aerobic conditions in duplicate. An additional bottle containing $3 \mathrm{~g}$ of sediment, $30 \mathrm{ml}$ artificial groundwater and $0.15 \mathrm{~g}$ of EHC was sterilised by autoclaving $\left(120^{\circ} \mathrm{C}, 20 \mathrm{mins}\right)$ and then spiked with $\mathrm{Tc}(\mathrm{VII})$ to assess the sorption of $\mathrm{Tc}$ to 
112 EHC in a sterile sediment system. The sorption of technetium to sediment was examined

113 using bottles comprising of $3 \mathrm{~g}$ of Sellafield sediment, $30 \mathrm{ml}$ artificial groundwater and

$114{ }^{99} \mathrm{Tc}(\mathrm{VII})$ in triplicate.

115 Te(VII) bioreduction and geochemistry: To investigate how the different electron donors 116 performed in stimulating Tc(VII) bioreduction, sediment microcosms were set up in $120 \mathrm{ml}$ 117 glass serum bottles in triplicate containing $10 \mathrm{~g}$ of Sellafield sediment, $100 \mathrm{ml}$ of artificial 118 groundwater, $0.5 \mathrm{~g}$ of $\mathrm{HRC}, \mathrm{MRC}$ or $\mathrm{EHC}$ and $100 \mathrm{~Bq} \mathrm{ml}^{-1}(1.6 \mu \mathrm{M}) \mathrm{Tc}(\mathrm{VII})$. The bottles were crimp sealed, the headspace degassed with argon, and then incubated in the dark at room temperature. A positive control contained $5 \mathrm{mM}$ acetate and $5 \mathrm{mM}$ lactate as a simple electron donor mix. A negative control for each slow-release electron donor was sterilised by autoclaving on two occasions, 24 hours apart before spiking with Tc(VII). slurry using a needle and syringe degassed with argon using aseptic technique. Iron(II) and total bioavailable iron in sediment slurry were assessed via digestion in $0.5 \mathrm{~N} \mathrm{HCl}$ or $0.25 \mathrm{~N}$ hydroxylamine hydrochloride in $0.5 \mathrm{~N} \mathrm{HCl}$, then measurement of $\mathrm{Fe}(\mathrm{II})$ and total $\mathrm{Fe}$ using

127 the ferrozine assay. ${ }^{52,53}$ The supernatant was separated from the sediment by centrifugation $(16,200 \mathrm{~g}, 5$ minutes$)$, and aqueous Tc was measured by liquid scintillation counting (background counts in "unspiked" liquid scintillation fluid averaged $(\mathrm{n}=38) 31.0 \pm 4.3 \mathrm{cpm}$, which defined a minimal detectable ${ }^{99}$ Tc concentration of $2.2 \mathrm{nM}^{54}$ ), nitrate, sulfate and volatile fatty acids (VFAs) by ion chromatography (Dionex ICS 5000), and pH and Eh were measured using calibrated electrodes. Gas samples were collected from the microcosm headspace and analysed for the presence of methane and hydrogen via gas chromatography

134 flame ionisation detection (GC-FID). ${ }^{55}$ 
135 Molecular ecology: To investigate the composition of the sediment microbial community, 136 DNA was extracted from sediment slurry samples using a PowerSoil DNA Isolation Kit (MO 137 BIO Laboratories INC, Carlsbad, CA, USA). Full details of the methodology are described

138 previously. ${ }^{49,56}$ Briefly, for archaeal polymerase chain reaction (PCR) amplification a 139 fragment of the 16S ribosomal RNA gene (approximately 940 base pairs) was amplified 140 using the primers $21 \mathrm{~F}$ and $958 \mathrm{R}^{57}$ and bacterial DNA was amplified using the universal $16 \mathrm{~S}$ 141 rRNA primers $8 \mathrm{~F}$ and $1492 \mathrm{R}^{58}$ The purity of the amplified products was determined by 142 electrophoresis in Tris-acetate-EDTA gel. PCR products were cleaned up, quantified, and 143 sequenced using a Roche 454 Life Sciences Junior System. Qiime 1.8.0 ${ }^{59}$ was used to 144 analyse the 454 pyrosequencing reads, the Ribosomal Database Project ${ }^{60}$ was used for 145 taxonomic classification, and Blastn was used to identify the closest GenBank matches 146 (http://blast.ncbi.nlm.nih.gov).

147 Speciation of solid-phase technetium: Selected higher radioactivity microcosms were set to investigate abiotic interactions between the ZVI within the EHC and Tc(VII). After 67 days incubation (EHC microcosms) or 91 days (HRC and MRC), the concentrations of $\mathrm{Fe}(\mathrm{II})^{52}$ and $\mathrm{Tc}_{\mathrm{aq}}$ were measured, then the experiment sampled to yield approximately $0.1 \mathrm{~g}$ of moist sediment paste, mounted in a standard sample cell and stored at $-80^{\circ} \mathrm{C}$ under argon prior to shipping to the Diamond Light Source, Harwell, UK for analysis. Samples were analysed using XAS on beamline B18 at liquid nitrogen temperature. ${ }^{61}$ Tc K edge spectra were collected in fluorescence mode using either a 9 or 36 element Ge detector. 
160 Oxidative remobilisation of Tc(IV): To examine how the different electron donors

161 influenced the oxidative remobilisation of Tc, a parallel set of microcosms were prepared and 162 subsequently reoxidised. Sediment microcosms (5 g Sellafield sediment and $50 \mathrm{ml}$ artificial 163 groundwater) were prepared in triplicate with $0.25 \mathrm{~g}$ of $\mathrm{HRC}, \mathrm{MRC}$ or $\mathrm{EHC}$ and $120 \mathrm{~Bq} \mathrm{ml}^{-1}$

$164(1.9 \mu \mathrm{M}){ }^{99} \mathrm{Tc}$. A positive control was prepared using a $5 \mathrm{mM}$ acetate and $5 \mathrm{mM}$ lactate 165 electron donor mix. A sterile control for the EHC experiment was prepared by autoclaving $166\left(120^{\circ} \mathrm{C}, 20\right.$ minutes) prior to spiking with ${ }^{99} \mathrm{Tc}(\mathrm{VII})$. After 60 days, the fully reduced 167 microcosms were reoxidised by decanting the sediment slurry into sterile $500 \mathrm{ml}$ bottles and 168 aerated daily by opening and shaking for 15 minutes. Sediment slurry was removed 169 periodically for geochemical analysis as described previously. Additional experiments were 170 carried out at higher Tc concentrations to investigate the oxidation state and speciation of 171 technetium by XAS following reoxidation. These contained $0.7 \mathrm{~g}$ sediment, $10 \mathrm{ml}$ artificial 172 groundwater, $25 \mathrm{kBq} \mathrm{ml}^{-1}(400 \mu \mathrm{M}) \mathrm{TcO}_{4}{ }^{-}$and $0.1 \mathrm{~g} \mathrm{HRC}, \mathrm{MRC}$ or EHC. After 139 days of 173 anaerobic incubation, the bottles were opened to air within a 5 litre container and shaken 174 gently on an orbital shaker.

\section{RESULTS AND DISCUSSION}

Initial testing of electron donors and Tc solubility: Addition of the three slow-release substrates to sediment microcosms lead to the reduction of more than $50 \%$ of the $0.5 \mathrm{~N}$ hydroxylamine- $\mathrm{HCl}$ extractable "bioavailable" iron within 8 days (Figure S1a), confirming the suitability of these electron donors to stimulate anaerobic processes in Sellafield sediment. The amount of "bioavailable" iron increased markedly in microcosms containing EHC and the majority of this was present as Fe(II) (Figure S1a). This effect was not observed in the systems without an additional iron source indicating that the ZVI in EHC was corroding to generate bioavailable Fe(II). 
In solubility tests, $\mathrm{Tc}(\mathrm{VII})$ at $100 \mathrm{~Bq} \mathrm{ml}^{-1}(1.6 \mu \mathrm{M})$ remained soluble in artificial groundwater containing $\mathrm{HRC}$ and MRC and, as expected, did not sorb to Sellafield sediment (Figure $\mathrm{S} 1 \mathrm{~b}$ ). The $\mathrm{pH}$ of the bottles containing HRC and MRC dropped to below 3 indicating that acidity had been generated, probably as lactic acid from the degradation of the substrates. ${ }^{51}$ When both sediment and substrate were present the $\mathrm{pH}$ dropped from 7 to around 6.2 (Figure S1a) suggesting the buffering capacity of the sediment counteracted this effect. Tc was removed rapidly from solution in the presence of both EHC and EHC with sterile sediment, confirming that an abiotic reaction with $\mathrm{Fe}(0)$ or $\mathrm{Fe}(\mathrm{II})$ likely dominated in these systems.

\section{Microbial reduction of $\mathrm{Te}(\mathrm{VII})$ and biogeochemistry: Sediment microcosms were} stimulated with the slow-release substrates to investigate their potential for technetium remediation. Geochemical results showed that Fe(II) was produced almost immediately with each slow-release amendment, indicating the rapid development of reducing conditions (Figure 1). Corrosion of ZVI in the EHC system lead to the highest measured concentrations of $0.5 \mathrm{~N} \mathrm{HCl}$ extractable $\mathrm{Fe}(\mathrm{II})$. Tc(VII) was removed from solution almost immediately with EHC, likely due to abiotic reduction by the Fe(II) to form poorly soluble Tc(IV) phases. $^{28,62}$ A lag of around four days was observed with the samples amended with HRC, MRC and the acetate/lactate mix, with Tc(VII) removal associated with the onset of microbial Fe(III)reducing conditions and subsequent abiotic reduction via Fe(II), to form poorly soluble Tc(IV) phases. This process has been observed in past experiments with representative Sellafield sediments stimulated with simple electron donors ${ }^{19}$ and in a range of biotic and abiotic systems containing Fe(II). ${ }^{4,16,48}$ Near-complete Tc removal was observed within 28 days in the experiments stimulated with MRC, EHC and the acetate/lactate mix, or after 90 days with HRC. The sterile controls containing HRC and MRC did not show significant removal of Tc(VII) from solution, nor did they produce Fe(II), confirming that these 
209 processes were microbially-mediated (Figure 1). Reflecting the results of the initial Tc

210 solubility experiments, Tc removal was also observed in the sterile control containing EHC,

211 again likely due to abiotic ZVI-mediated reduction to poorly soluble Tc(IV) phases. $^{28,62}$

212 X-ray absorption near edge structure (XANES) data from the experimental end points in

213 higher activity systems showed that the solid-phase samples were dominated by Tc(IV),

214 confirming reductive scavenging as the dominant mechanism for removal (Figure 2). Given

215 the presence of substantial amounts of $\mathrm{Fe}(\mathrm{II})$ in these experiments, it is likely that the removal

216 of Tc from solution occurred indirectly via microbial Fe(III)-reduction rather than direct

217 enzymatic Tc(VII) reduction, while in the presence of EHC, abiotic ZVI-mediated reduction

218 is likely to have been the dominant $\mathrm{Tc}_{\mathrm{aq}}$ removal process.

219 Analysis of anions showed very rapid removal of nitrate from solution (Figure S2).

$220 \mathrm{Tc}(\mathrm{VII})$ reduction generally occurred concurrently with Fe(II) production. Sulfate was fully

221 removed from solution within 90 days with each amendment suggesting sulfidic conditions

222 had developed. It is noteworthy that sulfate concentrations were higher in the MRC system

223 due to the presence of sulfur in the slow-release donor, and that in this experiment Tc

224 removal occurred at the same time as sulfate reduction (between days 4 and 14). Analysis of

225 VFAs, monitored as proxies for organic electron donors, showed that a complex mix of

226 organics was produced from each proprietary amendment (Figure S3). After 90 days,

227 significant quantities of VFAs remained in solution with the HRC and MRC amendments,

228 whilst the VFAs that had been produced in the EHC system were depleted by this point.

Gas was generated in each microbially-active experimental system, indicated by positive

pressure observed on sampling. This occurred rapidly in the microcosms containing EHC,

231 which were estimated to have produced more than $60 \mathrm{ml}$ of gas during the 90 day 
233 after 230 days incubation. Headspace analysis via GC-FID found that at these experimental 234 end-points, the gas was nearly 100\% methane. Furthermore, analysis of DNA extracted from 235 the sediment microcosms confirmed the presence of archaea consistent with simulation of 236 methanogenesis (Figure S4). Generating substantial volumes of gas is clearly undesirable for 237 in situ bioremediation applications as it could potentially cause pore blocking and alter 238 groundwater flow pathways. ${ }^{63}$ Furthermore methane is considered to be a hazardous ground 239 gas. $^{64}$ Although anecdotal evidence suggests that methane formation has not been observed 240 in field applications of slow-release electron donors, this clearly warrants further work in the context of remediation of nuclear licensed sites.

Molecular ecology: Samples were taken from sediment microcosms on Day 0 and Day 90 (HRC, MRC and EHC) and DNA present was extracted and analysed to investigate changes in the composition of the microbial community after biostimulation with slow-release substrates (Table S2). 16S rRNA pyrosequencing showed that a diverse range of soil bacteria was present at Day 0 (Figure 3, Table S3), and 90 days post-biostimulation the microbial community had shifted towards species associated with anaerobic conditions, which can be linked to maintaining reducing conditions and consequently low concentrations of $\mathrm{Tc}_{\mathrm{aq}}$ over prolonged time periods.

Following biostimulation with HRC, the microbial community at Day 90 was dominated by bacteria from the Mollicutes class of the Tenericutes phylum (51\%), Firmicutes (22\%) and Gammaproteobacteria (14\%) (Figure 3). Mollicutes are mostly facultative anaerobic bacteria $^{65}$, the two most abundant OTUs (operational taxonomic units) were from Mollicutes and comprised $50 \%$ of the microbial community (Table S3). These results are consistent HRC substrate. 
The microbial community that developed after biostimulation with MRC was again consistent with a marked shift to anoxia after biostimulation, and was dominated by bacteria from Firmicutes (72\%) and Gammaproteobacteria (21\%) (Figure 3). Four of five most abundant OTUs were most closely related to "Bacterium Irt-JG1-53" (Table S3) isolated from uranium mine waste ${ }^{66}$ and comprised $33 \%$ of the microbial community; these OTUs were assigned to Ruminococcus, a strictly anaerobic genus of heterotrophic bacteria. ${ }^{67} \mathrm{Six}$ OTUs were assigned to Desulfosporosinus meridiei, a known spore forming and sulfatereducing bacterium ${ }^{68}$ and previously detected in MRC-amended sediments. ${ }^{69}$ Desulfosporosinus meridiei was undetected in the Day 0 sample, but by Day 90 comprised $2.1 \%$ of the microbial community, consistent with the stimulation of sulfate reduction.

Biostimulation with EHC lead to a bacterial community dominated by Bacteroidetes (62\%) and Firmicutes (25\%) (Figure 3), and an archaeal community dominated by Crenarchaeota (67\%) and Euryarchaeota (33\%). Most bacteria within the Bacteriodales are either facultative or strict anaerobes and commonly found in organic-rich anaerobic environments. ${ }^{70,71}$ All five of the most abundant bacterial OTUs were assigned to Bacteroidales and were most closely related to uncultured bacteria from methane-rich or methanogenic environments (Table S3). All five of the most abundant archaeal OTUs were closely related to species associated with methanogenic environments (Table S3): two were assigned to the known methanogens Methanomassiliicoccaceae within the Euryarchaeota, while three were assigned to Crenarchaeota and closely related to uncultured species from methane-generating environments. This suggests that the microbial community was highly anaerobic and supports the biogenic origin of the methane produced after biostimulation of sediments with slow-release substrates.

Speciation of solid-phase technetium: Selected higher radioactivity solid samples were analysed using XAS to identify the speciation of Tc. The rate and extent of Tc removal were 
282 lower in these high level $\left(20 \mathrm{kBq} \mathrm{ml}^{-1}, 320 \mu \mathrm{M}\right)$ experiments compared to the low level $(0.1$ $\left.283 \mathrm{kBq} \mathrm{ml}^{-1}, 1.6 \mu \mathrm{M}\right)$ experiments as observed previously ${ }^{13}$ and suggesting some inhibition of bioreduction processes at elevated Tc concentrations (approximately $15-60 \%$ of Tc was removed within 120 days, see supporting information for further discussion).

Analysis of the XANES spectrum for the HRC sample, using linear combination fitting between standards for $\mathrm{Tc}(\mathrm{VII})$ as pertechnetate and $\mathrm{Tc}(\mathrm{IV})$ as $\mathrm{TcO}_{2}{ }^{72}$ indicated the sample contained approximately $75 \% \mathrm{Tc}(\mathrm{IV})$ and $25 \% \mathrm{Tc}(\mathrm{VII})$ (Figure 2). The $\mathrm{Tc}(\mathrm{VII})$ observed is most probably due to Tc(VII) in the pore-waters of the sample. Indeed, past workers have observed similar levels (15 - 50\%) of Tc(VII) in XANES from partially oxidised sediments. ${ }^{3,73}$ As the rate of reduction was slow in the HRC XAS experiments, a significant amount of Tc(VII) would certainly be present in the aqueous phase associated with the moist sediment pellet analysed using XAS. The EXAFS data were fitted assuming contributions of $75 \% \mathrm{Tc}(\mathrm{IV})$ as hydrous $\mathrm{TcO}_{2}$ and $25 \% \mathrm{Tc}(\mathrm{VII})$ as pertechnetate and using relevant $\mathrm{Tc}(\mathrm{IV})$ and Tc(VII) models from the literature. ${ }^{2,74,75,}$ Here, a good fit was obtained for the first peak with $4.4 \mathrm{O}$ atoms from $\mathrm{Tc}(\mathrm{IV})-\mathrm{O}$ at $2.01 \AA$ and $1 \mathrm{O}$ from $\mathrm{Tc}(\mathrm{VII})-\mathrm{O}$ at $1.65 \AA$ reflecting the improved by the addition of $1 \mathrm{Tc}$ atom at $2.58 \AA$ suggesting that the Tc(IV) may be present as hydrous $\mathrm{TcO}_{2}{ }^{2,76}$ Given that not all the Tc had been removed from solution in this sample, XANES analysis was attempted on the aqueous phase after 139 days ( $\sim 30 \mathrm{ppm}$ Tc $)$. Linear combination fitting of the resulting spectra between relevant Tc(IV) and Tc(VII) standards ${ }^{72}$ found $\sim 50 \%$ of $\mathrm{Tc}$ in the aqueous phase was present as $\mathrm{Tc}(\mathrm{IV})$ with $\sim 50 \%$ as $\mathrm{Tc}$ (VII) (Figure 2). This suggested that a significant fraction of the aqueous phase was present as Tc(IV) colloids or organic complexes, as reported in past studies. ${ }^{7,20,37,39}$ Clearly, the presence of a significant component of colloidal or organic-complexed Tc(IV) in these systems is potentially problematic and warrants further research. 
While the edge position confirmed that Tc(IV) was precipitated following biostimulation with MRC, both the XANES and the EXAFS were markedly different to the $\mathrm{TcO}_{2}$ standard and the other samples analysed (Figure 2, Figure S5) suggesting a different coordination environment in this sample. Inspection of the MRC Fourier transform showed the first shell was present at $2.36 \AA$ (Figure 4, Figure S5) which is consistent with a $\mathrm{TcS}_{2}$-like coordination environment ${ }^{6,26}$ and therefore the $\mathrm{TcS}_{2}$ crystal structure ${ }^{77}$ was used to inform the fitting. A good fit was obtained with $6 \mathrm{~S}$ atoms at $2.36 \AA$ and $2 \mathrm{Tc}$ atoms at $2.78 \AA$ (Table S4) confirming the formation of a $\mathrm{Tc}(\mathrm{IV}) \mathrm{S}_{2}$ phase, likely stimulated by the additional sulfur present in MRC. The microbially-mediated formation of $\mathrm{TcS}_{2}$ phases during stimulated sulfate reduction has been observed previously in both pure culture and sediment based systems ${ }^{7,9}$ although hydrous $\mathrm{TcO}_{2}$ phases are more commonly reported even in sulfate-rich marine environments. ${ }^{13}$ In one recent study on sediment systems, partial Tc-sulfide formation was stimulated by indigenous microorganisms over several months when the system was enriched in sulfate highlighting the link between elevated sulfur concentrations, long incubations and $\mathrm{TcS}_{2}$ formation. ${ }^{7}$

The edge position of Tc in both the EHC sediment, and the abiotic EHC no sediment systems confirmed that it was present as Tc(IV) (Figure 2). However, there were some modest differences between the EXAFS from these two samples, with a dampening of the oscillations around 9 and $11 \AA^{-1}$ in the EHC sediment system compared to the abiotic EHC spectrum, a greater height of the second peak in the Fourier transform of the EHC sediment spectrum, while the abiotic EHC spectrum showed some evidence for increased long range order to $\sim 3.4 \AA$ (Figure S5). The hydrous $\mathrm{TcO}_{2}$ model ${ }^{2}$ was used to fit these spectra. A good fit was obtained for the EHC sediment sample with six O atoms at $2.05 \AA$ and $2.1 \mathrm{Tc}$ atoms at $2.54 \AA$ (Figure 4, Table S4), suggesting the Tc(IV) was present as short-chain polymeric hydrous $\mathrm{TcO}_{2}{ }^{2,78}$ Recent work has highlighted the potential for attachment of short-chain 
332 hydrous $\mathrm{TcO}_{2}$ to surface $\mathrm{Fe}-\mathrm{O}$ octahedra. ${ }^{3,4,43,48}$ In the current study, the EHC sediment fit 333 was slightly improved with a "short Fe" contribution with $1.6 \mathrm{Tc}$ atoms at $2.55 \AA$ and with a 334 physically realistic contribution of $0.5 \mathrm{Fe}$ atoms at $2.56 \AA$ (Figure S6, Table S5), suggesting 335

to past work. ${ }^{4,48}$ A good fit was obtained for the EHC with no sediment with six $\mathrm{O}$ atoms at $2.05 \AA$ and two Tc atoms at $2.51 \AA$, again suggesting it was present in the form of short-chain polymeric hydrous $\mathrm{TcO}_{2}$ (Figure 4, Table S4).

Oxidative remobilisation of Tc(IV): Experiments were performed to investigate the potential for oxidative remobilisation of Tc(IV) in the treated sediments. These were designed to generate 'end member' highly oxidising conditions rather than simulate conditions that might be encountered in the subsurface. The results showed that the $\mathrm{Tc}(\mathrm{IV})$ formed with each of the slow-release amendments was recalcitrant to reoxidation with air, but this was not the case with the Tc(IV) produced after biostimulation with an acetate/lactate mix (Figure 5). Geochemical monitoring confirmed that oxidising conditions had been generated indicated by nitrate and sulfate in solution and $0.5 \mathrm{~N} \mathrm{HCl}$-extractable $\mathrm{Fe}(\mathrm{II})$ being reoxidised to Fe(III) (Figure S7).

For the HRC and MRC amendments, the lack of Tc(IV) reoxidation might be due to the presence of excess electron donors in the form of long-lived VFAs (Figure S8) which could be metabolised by the indigenous microbial community, offering some redox buffering to protect the Tc(IV). This effect has been observed previously, where the presence of electron donor buffered U(IV) from oxidative remobilisation. ${ }^{55}$ It is noteworthy that in these systems after the initial reoxidation of $\mathrm{Fe}(\mathrm{II})$ to $\mathrm{Fe}(\mathrm{III})$, it appeared that $\mathrm{Fe}(\mathrm{III})$-reduction recommenced, confirming that these systems were poised close to anaerobic conditions due to the presence of residual electron donor. Furthermore, in the MRC system there was little sulfate released to solution until the later stages of reoxidation (Figure S7). This suggests that 
357 the sulfide phases formed by microbial reduction, including $\mathrm{TcS}_{2}$, were recalcitrant to

358 reoxidation under these conditions and also acted as redox "buffers". Given that previous

359 research has also demonstrated that Tc(IV)-sulfides are more resistant to oxidative

360 remobilisation than Tc(IV)-oxides ${ }^{47}$ the use of electron donors that favour sulfidic conditions

361 such as MRC seem an appropriate bioremediation option for Tc-contaminated groundwaters,

362 although the impacts of sulfidation on other groundwater contaminants would need to be

363 considered further.

364 The sediments stimulated with EHC contained negligible amounts of VFAs after 14 days

365 of reoxidation. Likewise, less than $0.3 \mathrm{mM}$ VFAs were detected in solution in the sterile

366 EHC system throughout the course of the reduction and reoxidation experiments. Therefore

367 in both cases it is unlikely that the presence of VFAs played a dominant role in protecting

$368 \mathrm{Tc}(\mathrm{IV})$ in these systems. The majority of the $0.5 \mathrm{~N} \mathrm{HCl}$ extractable $\mathrm{Fe}(\mathrm{II})$ had been

369 reoxidised to $\mathrm{Fe}(\mathrm{III})$ in both the $\mathrm{EHC}$ and sterile $\mathrm{EHC}$ bottles by the end of reoxidation, but

370 despite this, the oxidative remobilisation of Tc(IV) was not observed. In this case, it is

371 possible that the unreacted ZVI or ZVI which had corroded to poorly leachable Fe(II)-bearing

372 phases such as magnetite may have buffered the system from reoxidation. ${ }^{3,48,79}$

373 It is noteworthy that Tc(IV) in the form of hydrous $\mathrm{Tc}(\mathrm{IV}) \mathrm{O}_{2}$ was generated by

374 biostimulation with HRC, EHC and acetate and lactate ${ }^{19}$ but only the Tc(IV) from

375 acetate/lactate biostimulation was reoxidised. This suggests that the redox buffering of the

376 slow-release substrates may be responsible for protecting the $\mathrm{Tc}(\mathrm{IV})$ from reoxidation.

377 Parallel higher radioactivity samples were prepared for XAS analysis to investigate the

378 speciation of Tc in these reoxidised systems. Again, the reaction rates in the higher Tc

379 experiments $\left(25 \mathrm{kBq} \mathrm{ml}^{-1}, 400 \mu \mathrm{M} \mathrm{Tc}\right)$ were lower than in the low level $\left(0.1 \mathrm{kBq} \mathrm{ml}^{-1} \mathrm{Tc}, 1.6\right.$

$380 \mu \mathrm{M})$ experiments. A reoxidation study was not performed on the high level HRC system 
381 given the considerable amounts of Tc(IV) remaining in the aqueous phase (Figure 2). Some 382 oxidative remobilisation of Tc(IV) in the high level MRC experiment occurred and a partially-reoxidised sample was collected for XAS analysis after 24 days of exposure to air when $63 \%$ of the Tc had remobilised to solution. The EXAFS data for this sample showed significant differences to the reduced $\mathrm{TcS}_{2}$ with a shift of the first peak to a shorter atomic distance (Figure S9). Fitting was informed by past work that suggested $\mathrm{TcS}_{2}$ can reoxidise to $\mathrm{Tc}(\mathrm{IV})$-oxides in air $^{6}$ and by the short-chain hydrous $\mathrm{TcO}_{2}$ model. ${ }^{2}$ Linear combination fitting of the EXAFS data suggested a $\sim 60 \%$ contribution from $\mathrm{TcS}_{2}$ and $\sim 40 \%$ contribution from short-chain hydrous $\mathrm{TcO}_{2}$; shell-by-shell fitting using these contributions generated a good fit and suggested that partial oxidation of the $\mathrm{TcS}_{2}$ to hydrous $\mathrm{TcO}_{2}$ had occurred (Figure 6, Table S6).

Minimal amounts of Tc(IV) (approximately 6\%) were reoxidised in the high level EHC sediment system after 89 days of exposure to air. XANES confirmed that Tc(IV) dominated in the reoxidised solid sample and EXAFS showed the reoxidised sample had a very similar coordination environment to the parallel reduced sample (Figure S9). Here, a good fit was obtained using the short-chain hydrous $\mathrm{TcO}_{2}$ capped with $\mathrm{Fe}$ model ${ }^{3,4,43,48}$ (Figure 6, Table S6). This is consistent with the iron-rich EHC environment and suggests that armouring of Tc(IV) by reoxidised Fe(III) $)^{3,48}$ could be occurring, or incorporation of the Tc(IV) into secondary Fe phases ${ }^{80-82}$, or that the system was redox buffered by residual ZVI.

\section{ENVIRONMENTAL IMPLICATIONS}

$\mathrm{Tc}(\mathrm{VII})$ is a problematic, mobile contaminant in groundwater at nuclear facilities. Here we showed that slow-release electron donors can stimulate microbially-reducing conditions to reduce $\mathrm{Tc}(\mathrm{VII})$ to $\mathrm{Tc}(\mathrm{IV})$, mostly via reduction mediated by reducing minerals. In addition, in the sterile EHC system we demonstrated that anaerobic corrosion of ZVI removed Tc(VII) from solution abiotically. However, colloidal or organic-complexed Tc(IV) was identified at 
406 higher Tc concentrations in the HRC system; this would be undesirable in the subsurface due

407 to the potential for increased radionuclide transport. The Tc in the systems treated with slow-

408 release substrates was resistant to oxidative remobilisation, presumably due to redox

409 buffering from residual organic electron donor in the HRC and MRC treatments and residual

410 abiotic $\mathrm{Fe}(0)$ or non-acid leachable Fe(II) in the EHC systems. This suggests the Tc(IV) is

411 likely to be stable over extended periods when slow-release substrates are used, and in

412 contrast to Tc behaviour during bioreduction with simple electron donors such as acetate and

413 lactate. This highlights the importance of redox buffering in maintaining low concentrations

414 of $\mathrm{Tc}_{\mathrm{aq}}$ for bioremediation at nuclear sites.

\section{$415 \quad$ ASSOCIATED CONTENT}

416 Supporting Information. Additional results including tables and figures showing additional 417 geochemical and microbiological results are available free of charge via the Internet at 418 http://pubs.acs.org.

\section{$419 \quad$ AUTHOR INFORMATION}

420 Corresponding Author

421 * L. Newsome. Phone: +44 (0)161 275 0309; Email: laura.newsome@manchester.ac.uk.

\section{Notes}

423 The authors declare no competing financial interest.

\section{Acknowledgements}

425 We thank Christopher Boothman (University of Manchester) for assistance with sample 426 preparation and processing of pyrosequencing data, Nick Atherton (Sellafield Ltd) for 427 providing the sediment sample, Genevieve Boshoff and Divyesh Trivedi (National Nuclear 428 Laboratory) and Regenesis and Peroxychem for providing samples of the slow-release 
substrates. Beamtime at beamline B18 was funded by grants SP10163-1, SP10163-2 and SP13559-2 from Diamond Light Source. We acknowledge financial support from the Nuclear Decommissioning Authority via a PhD student bursary, managed by the National Nuclear Laboratory. JRL acknowledges the support of the Royal Society via an Industrial Fellowship and Wolfson Merit Award. We also acknowledge financial support from NERC via the BIGRAD consortium (NE/H007768/1) and the CoG3 consortium (NE/M011518/1).

\section{REFERENCES}

(1) Icenhower, J. P.; Qafoku, N. P.; Zachara, J. M.; Martin, W. J. The biogeochemistry of technetium: A review of the behavior of an artificial element in the natural environment. Am. J. Sci. 2010, 310, 721-752.

(2) Lukens, W. W.; Bucher, J. J.; Edelstein, N. M.; Shuh, D. K. Products of pertechnetate radiolysis in highly alkaline solution: Structure of $\mathrm{TcO}_{2} \cdot \mathrm{x}_{2} \mathrm{O}$. Environ. Sci. Technol. 2002, 36 (5), 1124-1129.

(3) Fredrickson, J. K.; Zachara, J. M.; Plymale, A. E.; Heald, S. M.; McKinley, J. P.; Kennedy, D. W.; Liu, C.; Nachimuthu, P. Oxidative dissolution potential of biogenic and abiogenic $\mathrm{TcO}_{2}$ in subsurface sediments. Geochim. Cosmochim. Acta 2009, 73, 2299-2313.

(4) Brookshaw, D. R.; Pattrick, R. A. D.; Bots, P.; Law, G. T. W.; Lloyd, J. R.; Mosselmans, J. F. W.; Vaughan, D. J.; Dardenne, K.; Morris, K. Redox interactions of $\mathrm{Tc}(\mathrm{VII}), \mathrm{U}(\mathrm{VI})$, and $\mathrm{Np}(\mathrm{V})$ with microbially reduced biotite and chlorite. Environ. Sci. Technol. 2015, 49 (22), 13139-13148.

(5) Liu, J.; Pearce, C. I.; Qafoku, O.; Arenholz, E.; Heald, S. M.; Rosso, K. M. Tc(VII) reduction kinetics by titanomagnetite $\left(\mathrm{Fe}_{3-\mathrm{x}} \mathrm{Ti}_{\mathrm{x}} \mathrm{O}_{4}\right)$ nanoparticles. Geochim. Cosmochim. Acta 2012, 92, 67-81.

(6) Wharton, M. J.; Atkins, B.; Charnockab, J. M.; Livens, F. R.; Pattrick, R. A. D.; Collison, D. An X-ray absorption spectroscopy study of the coprecipitation of Tc and Re with mackinawite (FeS). Appl. Geochem. 2000, 15, 347-354.

(7) Lee, J.-H.; Zachara, J. M.; Fredrickson, J. K.; Heald, S. M.; McKinley, J. P.; Plymale, A. E.; Resch, C. T.; Moore, D. A. Fe(II)- and sulfide-facilitated reduction of ${ }^{99} \mathrm{Tc}$ (VII)O ${ }_{4}^{-}$in microbially reduced hyporheic zone sediments. Geochim. Cosmochim. Acta 2014, 136, 247-264.

(8) Lloyd, J. R.; Cole, J. A.; Macaskie, L. E. Reduction and removal of heptavalent technetium from solution by Escherichia coli. J. Bacteriol. 1997, 179, 2014-2021.

(9) Lloyd, J. R.; Nolting, H. F.; Sole, V. A.; Bosecker, K. Technetium reduction and precipitation by sulfate-reducing bacteria. Geomicrobiol. J. 1998, 15, 45-58.

(10) Lyalikova, N. N.; Khizhnyak, T. V. Reduction of heptavalent technetium by acidophilic bacteria of the genus Thiobacillus. Microbiology 1996, 65, 468-473. 
(11) Lovley, D. R. Bioremediation of organic and metal contaminants with dissimilatory iron reduction. J. Ind. Microbiol. 1995, 14, 85-93.

(12) Newsome, L.; Morris, K.; Lloyd, J. R. The biogeochemistry and bioremediation of uranium and other priority radionuclides. Chem. Geol. 2014, 363, 164-184.

(13) Burke, I. T.; Boothman, C.; Lloyd, J. R.; Mortimer, R. J. G.; Livens, F. R.; Morris, K. Effects of progressive anoxia on the solubility of technetium in sediments. Environ. Sci. Technol. 2005, 39, 4109-4116.

(14) Lloyd, J. R.; Sole, V. A.; Van Praagh, C. V. G.; Lovley, D. R. Direct and Fe(II)mediated reduction of technetium by $\mathrm{Fe}(\mathrm{III})$-reducing bacteria. Appl. Environ. Microbiol. 2000, 66, 3743-3749.

(15) Lloyd, J. R.; Thomas, G. H.; Finlay, J. A.; Cole, J. A.; Macaskie, L. E. Microbial reduction of technetium by Escherichia coli and Desulfovibrio desulfuricans: Enhancement via the use of high-activity strains and effect of process parameters. Biotechnol. Bioeng. 1999, 66, 122-130.

(16) McBeth, J. M.; Lear, G.; Lloyd, J. R.; Livens, F. R.; Morris, K.; Burke, I. T. Technetium reduction and reoxidation in aquifer sediments. Geomicrobiol. J. 2007, 24, 189-197.

(17) McBeth, J. M.; Lloyd, J. R.; Law, G. T. W.; Livens, F. R.; Burke, I. T.; Morris, K. Redox interactions of technetium with iron-bearing minerals. Mineral. Mag. 2011, 75, 2419-2430.

(18) Istok, J. D.; Senko, J. M.; Krumholz, L. R.; Watson, D.; Bogle, M. A.; Peacock, A.; Chang, Y. J.; White, D. C. In situ bioreduction of technetium and uranium in a nitratecontaminated aquifer. Environ. Sci. Technol. 2004, 38, 468-475.

(19) Law, G. T. W.; Geissler, A.; Boothman, C.; Burke, I. T.; Livens, F. R.; Lloyd, J. R.; Morris, K. Role of nitrate in conditioning aquifer sediments for technetium bioreduction. Environ. Sci. Technol. 2010, 44 (1), 150-155.

(20) Wildung, R. E.; Li, S. W.; Murray, C. J.; Krupka, K. M.; Xie, Y.; Hess, N. J.; Roden, E. E. Technetium reduction in sediments of a shallow aquifer exhibiting dissimilatory iron reduction potential. FEMS Microbiol. Ecol. 2004, 49, 151-162.

(21) Adamson, D. T.; McDade, J. M.; Hughes, J. B. Inoculation of a DNAPL source zone to initiate reductive dechlorination of PCE. Environ. Sci. Technol. 2003, 37 (11), $2525-2533$.

(22) Faybishenko, B.; Hazen, T. C.; Long, P. E.; Brodie, E. L.; Conrad, M. E.; Hubbard, S. S.; Christensen, J. N.; Joyner, D.; Borglin, S. E.; Chakraborty, R.; Williams, K. H.; Peterson, J. E.; Chen, J.; Brown, S.T.; Tokunaga, T. K.; Wan, J.; Firestone, M.; Newcomer, D. R.; Resch, C.T.; Cantrell, K. J.; Willett, A.; Koenigsberg, S. In situ long-term reductive bioimmobilization of $\mathrm{Cr}(\mathrm{VI})$ in groundwater using Hydrogen Release Compound. Environ. Sci. Technol. 2008, 42 (22), 8478-8485.

(23) Tang, G.; Watson, D. B.; Wu, W.-M.; Schadt, C. W.; Parker, J. C.; Brooks, S. C. $\mathrm{U}(\mathrm{VI})$ bioreduction with emulsified vegetable oil as the electron donor - model application to a field test. Environ. Sci. Technol. 2013, 47, 3218-3225.

(24) Watson, D. B.; Wu, W.-M.; Mehlhorn, T.; Tang, G.; Earles, J.; Lowe, K.; Gihring, T. M.; Zhang, G.; Phillips, J.; Boyanov, M. I.; Spalding, B. P.; Schadt, C.; Kemner, K. 
M.; Criddle, C. S.; Jardine, P. M.; Brooks, S. C. In situ bioremediation of uranium with emulsified vegetable oil as the electron donor. Environ. Sci. Technol. 2013, 47 (12), 6440-6448.

(25) Zhang, P.; Van Nostrand, J. D.; He, Z.; Chakraborty, R.; Deng, Y.; Curtis, D.; Fields, M. W.; Hazen, T. C.; Arkin, A. P.; Zhou, J. A slow-release substrate stimulates groundwater microbial communities for long-term in situ $\mathrm{Cr}(\mathrm{VI})$ reduction. Environ. Sci. Technol. 2015, 49 (21), 12922-12931.

(26) Fan, D.; Anitori, R. P.; Tebo, B. M.; Tratnyek, P. G.; Lezama Pacheco, J. S.; Kukkadapu, R. K.; Engelhard, M. H.; Bowden, M. E.; Kovarik, L.; Arey, B. W. Reductive sequestration of pertechnetate $\left({ }^{99} \mathrm{TcO}_{4}{ }^{-}\right)$by nano zerovalent iron (nZVI) transformed by abiotic sulfide. Environ. Sci. Technol. 2013, 47 (10), 5302-5310.

(27) Liang, L.; Gu, B.; Yin, X. Removal of technetium-99 from contaminated groundwater with sorbents and reductive materials. Sep. Technol. 1996, 6 (2), 111-122.

(28) Cantrell, K. J.; Kaplan, D. I.; Wietsma, T. W. Zero-valent iron for the in situ remediation of selected metals in groundwater. J. Hazard. Mater. 1995, 42 (2), 201212.

(29) Scherer, M. M.; Richter, S.; Valentine, R. L.; Alvarez, P. J. J. Chemistry and microbiology of permeable reactive barriers for in situ groundwater clean up. Crit. Rev. Microbiol. 2000, 26 (4), 221-264.

(30) Liang, L.; Korte, N.; Gu, B.; Puls, R.; Reeter, C. Geochemical and microbial reactions affecting the long-term performance of in situ "iron barriers." Adv. Environ. Res. 2000, 4 (4), 273-286.

(31) Lovley, D. R.; Phillips, E. J. P.; Lonergan, D. J. Hydrogen and formate oxidation coupled to dissimilatory reduction of iron or manganese by Alteromonas putrefaciens. Appl. Environ. Microbiol. 1989, 55, 700-706.

(32) Lovley, D. R.; Holmes, D. E.; Nevin, K. P. Dissimilatory Fe(III) and Mn(IV) reduction. In Advances in Microbial Physiology, Volume 49; Poole, R. K., Ed.; Academic Press, 2004; pp 219.

(33) Muyzer, G.; Stams, A. J. M. The ecology and biotechnology of sulphate-reducing bacteria. Nat. Rev. Microbiol. 2008, 6 (6), 441-454.

(34) Nedwell, D. B.; Banat, I. M. Hydrogen as an electron donor for sulfate-reducing bacteria in slurries of salt marsh sediment. Microb. Ecol. 1981, 7 (4), 305-313.

(35) Lloyd, J. R.; Ridley, J.; Khizniak, T.; Lyalikova, N. N.; Macaskie, L. E. Reduction of technetium by Desulfovibrio desulfuricans: Biocatalyst characterization and use in a flowthrough bioreactor. Appl. Environ. Microbiol. 1999, 65, 2691-2696.

(36) De Luca, G.; De Philip, P.; Dermoun, Z.; Rousset, M.; Vermeglio, A. Reduction of technetium(VII) by Desulfovibrio fructosovorans is mediated by the nickel-iron hydrogenase. Appl. Environ. Microbiol. 2001, 67, 4583-4587.

(37) Shi, L.; Belchik, S. M.; Plymale, A. E.; Heald, S.; Dohnalkova, A. C.; Sybirna, K.; Bottin, H.; Squier, T. C.; Zachara, J. M.; Fredrickson, J. K. Purification and characterization of the [NiFe]-hydrogenase of Shewanella oneidensis MR-1. Appl. Environ. Microbiol. 2011, 77 (16), 5584-5590. 
(38) Wildung, R. E.; Gorby, Y. A.; Krupka, K. M.; Hess, N. J.; Li, S. W.; Plymale, A. E.; McKinley, J. P.; Fredrickson, J. K. Effect of electron donor and solution chemistry on products of dissimilatory reduction of technetium by Shewanella putrefaciens. Appl. Environ. Microbiol. 2000, 66, 2451-2460.

(39) Plymale, A. E.; Fredrickson, J. K.; Zachara, J. M.; Dohnalkova, A. C.; Heald, S. M.; Moore, D. A.; Kennedy, D. W.; Marshall, M. J.; Wang, C.; Resch, C. T.; Nachimuthu, P. Competitive reduction of pertechnetate $\left({ }^{99} \mathrm{TcO}_{4}{ }^{-}\right)$by dissimilatory metal reducing bacteria and biogenic Fe(II). Environ. Sci. Technol. 2011, 45 (3), 951-957.

(40) Marshall, M. J.; Plymale, A. E.; Kennedy, D. W.; Shi, L.; Wang, Z. M.; Reed, S. B.; Dohnalkova, A. C.; Simonson, C. J.; Liu, C. X.; Saffarini, D. A.; Romine, M. F.; Zachara, J. M.; Beliaev, A. S.; Fredrickson, J. K. Hydrogenase- and outer membrane $c$ type cytochrome-facilitated reduction of technetium(VII) by Shewanella oneidensis MR-1. Environ. Microbiol. 2008, 10, 125-136.

(41) Lear, G.; McBeth, J. M.; Boothman, C.; Gunning, D. J.; Ellis, B. L.; Lawson, R. S.; Morris, K.; Burke, I. T.; Bryan, N. D.; Brown, A. P.; Livens, F. R.; Lloyd, J. R. Probing the biogeochemical behavior of technetium using a novel nuclear imaging approach. Environ. Sci. Technol. 2010, 44, 156-162.

(42) Thorpe, C. L.; Lloyd, J. R.; Law, G. T. W.; Williams, H. A.; Atherton, N.; Cruickshank, J. H.; Morris, K. Retention of ${ }^{99 \mathrm{~m}} \mathrm{Tc}$ at ultra-trace levels in flowing column experiments - insights into bioreduction and biomineralization for remediation at nuclear facilities. Geomicrobiol. J. 2016, 33 (3-4), 199-205.

(43) Morris, K.; Livens, F. R.; Charnock, J. M.; Burke, I. T.; McBeth, J. M.; Begg, J. D. C.; Boothman, C.; Lloyd, J. R. An X-ray absorption study of the fate of technetium in reduced and reoxidised sediments and mineral phases. Appl. Geochem. 2008, 23, 603617.

(44) Begg, J. D. C.; Burke, I. T.; Charnock, J. M.; Morris, K. Technetium reduction and reoxidation behaviour in Dounreay soils. Radiochim. Acta 2008, 96, 631-636.

(45) Critical review of the chemistry and thermodynamics of technetium and some of its inorganic compounds and aqueous species; UCRL-53440; Lawrence Livermore National Laboratory; Livermore, California, USA, 1983; http://www.osti.gov/servlets/purl/5580852/.

(46) Environmental geochemistry of radioactive contamination; SAND2003-2063; Sandia National Laboratories; Alberquerque, New Mexico, USA, 2003; http://infoserve.sandia.gov/sand_doc/2003/032063.pdf.

(47) Fan, D.; Anitori, R. P.; Tebo, B. M.; Tratnyek, P. G.; Lezama Pacheco, J. S.; Kukkadapu, R. K.; Kovarik, L.; Engelhard, M. H.; Bowden, M. E. Oxidative remobilization of technetium sequestered by sulfide-transformed nano zerovalent iron. Environ. Sci. Technol. 2014, 48 (13), 7409-7417.

(48) Zachara, J. M.; Heald, S. M.; Jeon, B. H.; Kukkadapu, R. K.; Liu, C. X.; McKinley, J. P.; Dohnalkova, A. C.; Moore, D. A. Reduction of pertechnetate Tc(VII) by aqueous $\mathrm{Fe}(\mathrm{II})$ and the nature of solid phase redox products. Geochim. Cosmochim. Acta 2007, $71,2137-2157$.

(49) Newsome, L.; Morris, K.; Trivedi, D.; Atherton, N.; Lloyd, J. R. Microbial reduction of uranium(VI) in sediments of different lithologies collected from Sellafield. Appl. 
Geochem. 2014, 51, 55-64.

(50) Wilkins, M. J.; Livens, F. R.; Vaughan, D. J.; Beadle, I.; Lloyd, J. R. The influence of microbial redox cycling on radionuclide mobility in the subsurface at a low-level radioactive waste storage site. Geobiology 2007, 5, 293-301.

(51) Koenigsberg, S. Hydrogen Release Compound (HRC): A novel technology for the bioremediation of chlorinated hydrocarbons. In Proceedings of the 1999 Conference on Hazardous Waste Research; 1999; p 14.

(52) Lovley, D. R.; Phillips, E. J. Organic matter mineralization with reduction of ferric iron in anaerobic sediments. Appl. Environ. Microbiol. 1986, 51 (4), 683-689.

(53) Lovley, D. R.; Phillips, E. J. P. Rapid assay for microbially reducible ferric iron in aquatic sediments. Appl. Environ. Microbiol. 1987, 53 (7), 1536-1540.

(54) Currie, L. A. Limits for qualitative detection and quantitative determination. Application to radiochemistry. Anal. Chem. 1968, 40 (3), 586-593.

(55) Newsome, L.; Morris, K.; Shaw, S.; Trivedi, D.; Lloyd, J. R. The stability of microbially reduced U(IV); impact of residual electron donor and sediment ageing. Chem. Geol. 2015, 409, 125-135.

(56) Newsome, L.; Morris, K.; Trivedi, D.; Bewsher, A.; Lloyd, J. R. Biostimulation by glycerol phosphate to precipitate recalcitrant uranium(IV) phosphate. Environ. Sci. Technol. 2015, 49 (18), 11070-11078.

(57) DeLong, E. F. Archaea in coastal marine environments. Proc. Natl. Acad. Sci. 1992, $89(12), 5685-5689$.

(58) Lane, D. J. 16S/23S rRNA sequencing. In Nucleic acid techniques in bacterial systematics; Stackebrant, E., Goodfellow, M., Eds.; John Wiley \& Sons Ltd: London, 1991; pp 115.

(59) Caporaso, J. G.; Kuczynski, J.; Stombaugh, J.; Bittinger, K.; Bushman, F. D.; Costello, E. K.; Fierer, N.; Peña, A. G.; Goodrich, J. K.; Gordon, J. I.; Huttley, G. A.; Kelley, S.T.; Knights, D.; Koenig, J. E.; Ley, R. E.; Lozupone, C. A.; McDonald, D.; Muegge, B. D.; Pirrung, M.; Reeder, J.; Sevinsky, J. R.; Turnbaugh, P. J.; Walters, W. A.; Widmann, J.; Yatsunenko, T.; Zaneveld, J.; Knight, R. QIIME allows analysis of highthroughput community sequencing data. Nat. Methods 2010, 7 (5), 335-336.

(60) Cole, J. R.; Wang, Q.; Cardenas, E.; Fish, J.; Chai, B.; Farris, R. J.; Kulam-SyedMohideen, A. S.; McGarrell, D. M.; Marsh, T.; Garrity, G. M.; Tiedje, J. M. The Ribosomal Database Project: improved alignments and new tools for rRNA analysis. Nucleic Acids Res. 2009, 37, D141-5.

(61) Dent, A. J.; Cibin, G.; Ramos, S.; Smith, A. D.; Scott, S. M.; Varandas, L.; Pearson, M. R.; Krumpa, N. A.; Jones, C. P.; Robbins, P. E. B18: A core XAS spectroscopy beamline for Diamond. J. Phys. Conf. Ser. 2009, 190 (1), 12039.

(62) Darab, J. G.; Amonette, A. B.; Burke, D. S. D.; Orr, R. D.; Ponder, S. M.; Schrick, B.; Mallouk, T. E.; Lukens, W. W.; Caulder, D. L.; Shuh, D. K. Removal of pertechnetate from simulated nuclear waste streams using supported zerovalent iron. Chem. Mater. 2007, 19 (23), 5703-5713.

(63) Sanchez de Lozada, D.; Vandevivere, P.; Baveye, P.; Zinder, S. Decrease of the 
hydraulic conductivity of sand columns by Methanosarcina barkeri. World J. Microbiol. Biotechnol. 1994, 10 (3), 325-333.

(64) Assessing risks posed by hazardous ground gases to buildings; CIRIA C665; CIRIA, London, England, 2007; http://www.ciria.org/ProductExcerpts/C665.aspx.

(65) Brown, D. R. Phylum XVI. Tenericutes Murray 1984a, 356VP (Effective publication: Murray 1984b, 33.). In Bergey's Manual ${ }^{\circledR}$ of Systematic Bacteriology Volume 4; Krieg, N. R., Ludwig, W., Whitman, W. B., Hedlund, B. P., Paster, B. J., Staley, J. T., Ward, N. L., Brown, D. R., Parte, A., Eds.; Springer New York: New York, NY, 2010; pp 567.

(66) Selenska-Pobell, S. Diversity and activity of bacteria in uranium waste piles. In Interactions of Microorganisms with Radionuclides; Keith-Roach, M. J., Livens, F. R., Eds.; Elsevier, 2002; pp 225.

(67) Schleifer, K.-H. Phylum XIII. Firmicutes Gibbons and Murray 1978, 5 (Firmacutes [sic] Gibbons and Murray 1978, 5). In Bergey's Manual ${ }^{\circledR}$ of Systematic Bacteriology Volume 3; Vos, P., Garrity, G., Jones, D., Krieg, N. R., Ludwig, W., Rainey, F. A., Schleifer, K. -H., Whitman, W., Eds.; Springer New York: New York, NY, 2009; pp 19.

(68) Robertson, W. J.; Bowman, J. P.; Franzmann, P. D.; Mee, B. J. Desulfosporosinus meridiei sp. nov., a spore-forming sulfate-reducing bacterium isolated from gasolenecontaminated groundwater. Int. J. Syst. Evol. Microbiol. 2001, 51 (Pt 1), 133-140.

(69) Brodie, E. L.; Joyner, D. C.; Faybishenko, B.; Conrad, M. E.; Rios-Velazquez, C.; Malave, J.; Martinez, R.; Mork, B.; Willett, A.; Koenigsberg, S.; Herman, D. J.; Firestone, M. K.; Hazen, T. C. Microbial community response to addition of polylactate compounds to stimulate hexavalent chromium reduction in groundwater. Chemosphere 2011, 85 (4), 660-665.

(70) Krieg, N. R.; Ludwig, W.; Euzéby, J.; Whitman, W. B. Phylum XIV. Bacteroidetes phyl. nov. In Bergey's Manual ${ }^{\circledR}$ of Systematic Bacteriology Volume 4; Krieg, N. R., Ludwig, W., Whitman, W. B., Hedlund, B. P., Paster, B. J., Staley, J. T., Ward, N. L., Brown, D. R., Parte, A., Eds.; Springer New York: New York, NY, 2010; pp 25.

(71) Tourlousse, D. M.; Matsuura, N.; Sun, L.; Toyonaga, M.; Kuroda, K.; Ohashi, A.; Cruz, R.; Yamaguchi, T.; Sekiguchi, Y. Draft genome sequence of Bacteroidales strain $\mathrm{TBC} 1$, a novel isolate from a methanogenic wastewater treatment system. Genome Announc. 2015, 3 (5), e01168-15.

(72) Hess, N. J.; Xia, Y.; Rai, D.; Conradson, S. D. Thermodynamic model for the solubility of $\mathrm{TcO}_{2} \cdot \mathrm{XH}_{2} \mathrm{O}(\mathrm{am})$ in the aqueous $\mathrm{Tc}(\mathrm{IV})-\mathrm{Na}^{+}-\mathrm{Cl}^{-}-\mathrm{H}^{+}-\mathrm{OH}^{-}-\mathrm{H}_{2} \mathrm{O}$ system. $J$. Solution Chem. 2004, 33 (2), 199-226.

(73) Burke, I. T.; Boothman, C.; Lloyd, J. R.; Livens, F. R.; Charnock, J. M.; McBeth, J. M.; Mortimer, R. J. G.; Morris, K. Reoxidation behavior of technetium, iron, and sulfur in estuarine sediments. Environ. Sci. Technol. 2006, 40, 3529-3535.

(74) Faggiani, R.; Gillespie, R. J.; Lock, C. J. L.; Pocé, J. The structure of ammonium pertechnetate at 295, 208 and 141 K. Acta Crystallogr. Sect. B Struct. Crystallogr. Cryst. Chem. 1980, 36 (2), 231-233.

(75) Rodriguez, E. E.; Poineau, F.; Llobet, A.; Sattelberger, A. P.; Bhattacharjee, J.; 
Waghmare, U. V; Hartmann, T.; Cheetham, A. K. Structural studies of $\mathrm{TcO}_{2}$ by neutron powder diffraction and first-principles calculations. J. Am. Chem. Soc. 2007, 129 (33), 10244-10248.

(76) Peretyazhko, T.; Zachara, J. M.; Heald, S. M.; Jeon, B. H.; Kukkadapu, R. K.; Liu, C.; Moore, D.; Resch, C. T. Heterogeneous reduction of Tc(VII) by Fe(II) at the solidwater interface. Geochim. Cosmochim. Acta 2008, 72, 1521-1539.

(77) Lamfers, H.-J.; Meetsma, A.; Wiegers, G. A.; de Boer, J. L. The crystal structure of some rhenium and technetium dichalcogenides. J. Alloys Compd. 1996, 241 (1-2), 3439.

(78) Peretyazhko, T.; Zachara, J. M.; Heald, S. M.; Kukkadapu, R. K.; Liu, C.; Plymale, A. E.; Resch, C. T. Reduction of Tc(VII) by Fe(II) sorbed on Al (hydr)oxides. Environ. Sci. Technol. 2008, 42, 5499-5506.

(79) Cui, D.; Eriksen, T. E. Reduction of pertechnetate in solution by heterogeneous electron transfer from Fe(II)-containing geological material. Environ. Sci. Technol. 1996, 30 (7), 2263-2269.

(80) Skomurski, F. N.; Rosso, K. M.; Krupka, K. M.; McGrail, B. P. Technetium incorporation into hematite $\left(\alpha-\mathrm{Fe}_{2} \mathrm{O}_{3}\right)$. Environ. Sci. Technol. 2010, 44 (15), 58555861.

(81) Marshall, T. A.; Morris, K.; Law, G. T. W.; Mosselmans, J. F. W.; Bots, P.; Parry, S. A.; Shaw, S. Incorporation and retention of ${ }^{99}-\mathrm{Tc}(\mathrm{IV})$ in magnetite under high $\mathrm{pH}$ conditions. Environ. Sci. Technol. 2014, 48 (20), 11853-11862.

(82) Smith, F. N.; Taylor, C. D.; Um, W.; Kruger, A. A. Technetium incorporation into goethite $(\alpha-\mathrm{FeOOH})$ : An atomic-scale investigation. Environ. Sci. Technol. 2015, 49 (22), 13699-13707. 


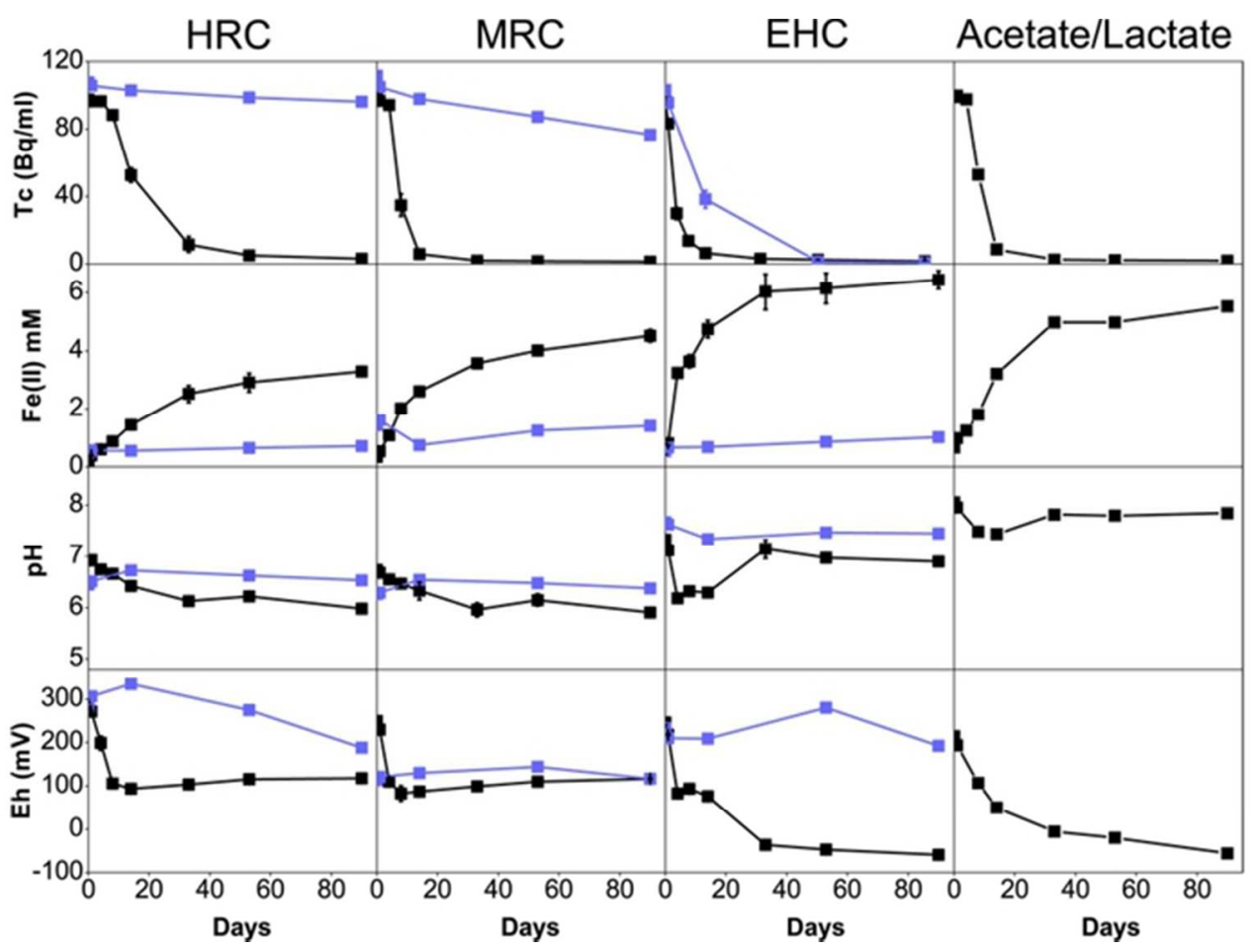

Figure 1. Results of microbial Tc(VII) reduction experiments. Black lines indicate biostimulated triplicate microcosms, blue lines are sterile controls. Points represent the average of three measurements, error bars +/- 1 SD. The acetate/lactate microcosm was a positive control.

$60 \times 43 \mathrm{~mm}(300 \times 300$ DPI $)$ 


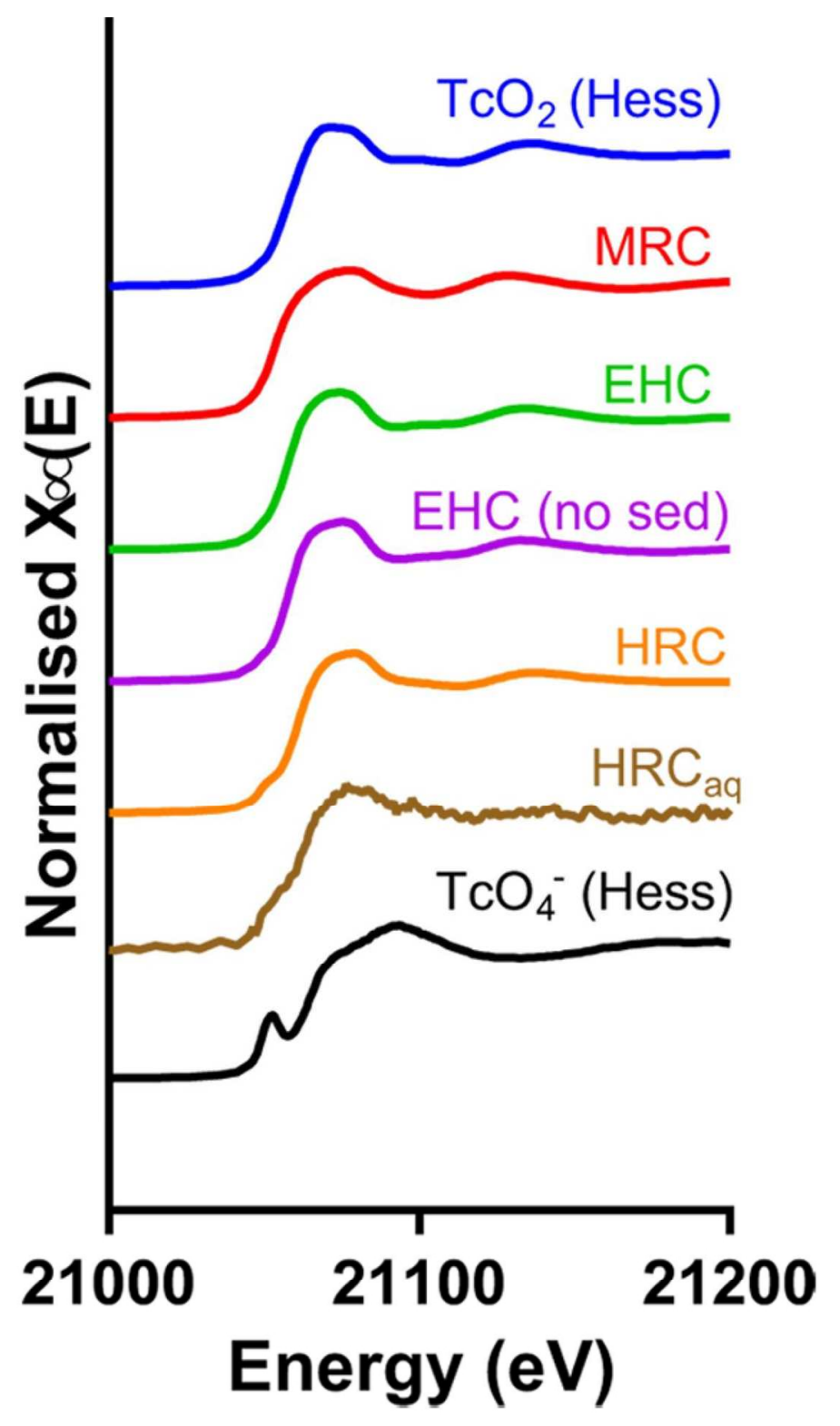

Figure 2. Solid phase XANES data showing reduction of $T c(V I I)$ to $T c(I V)$ following amendment of sediments with slow-release substrates, or EHC with no sediment 'no sed' and aqueous phase XANES for the HRC amended sample. There is a clear but minor pre-edge $\mathrm{Tc}(\mathrm{VII})$ feature in the HRC amended sediment. The $\mathrm{Tc}(\mathrm{IV})$ and $\mathrm{Tc}(\mathrm{VII})$ standards are from Hess et al.72

$$
83 \times 137 \mathrm{~mm}(300 \times 300 \mathrm{DPI})
$$




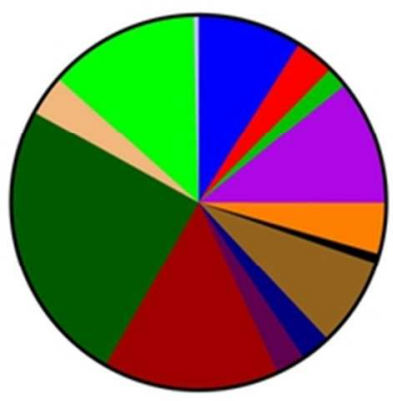

Day 0

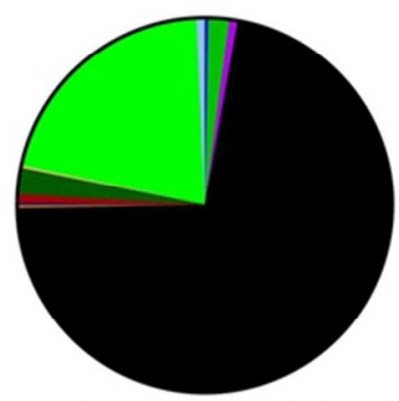

Day 90 post MRC

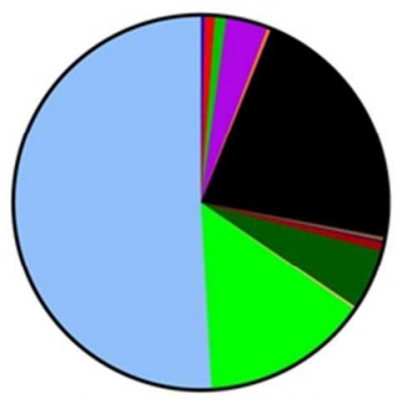

Day 90 post HRC

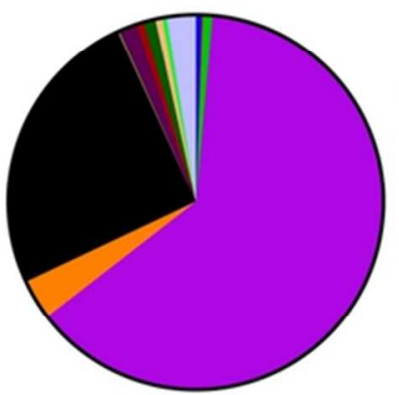

Day 90 post EHC
Acidobacteria
Actinobacteria
Bacteria;Other
Bacteroidetes

Chloroflexi

Firmicutes

Gemmatimonadetes

Nitrospirae

Planctomycetes

Betaproteobacteria

Deltaproteobacteria

Gammaproteobacteria

Tenericutes

Verrucomicrobia

Figure 3. Bacterial phylogenetic diversity within Sellafield sediments after stimulation with HRC, MRC and EHC. Phyla/classes detected at greater than $1 \%$ of the bacterial community are illustrated.

$$
60 \times 42 \mathrm{~mm}(300 \times 300 \text { DPI })
$$



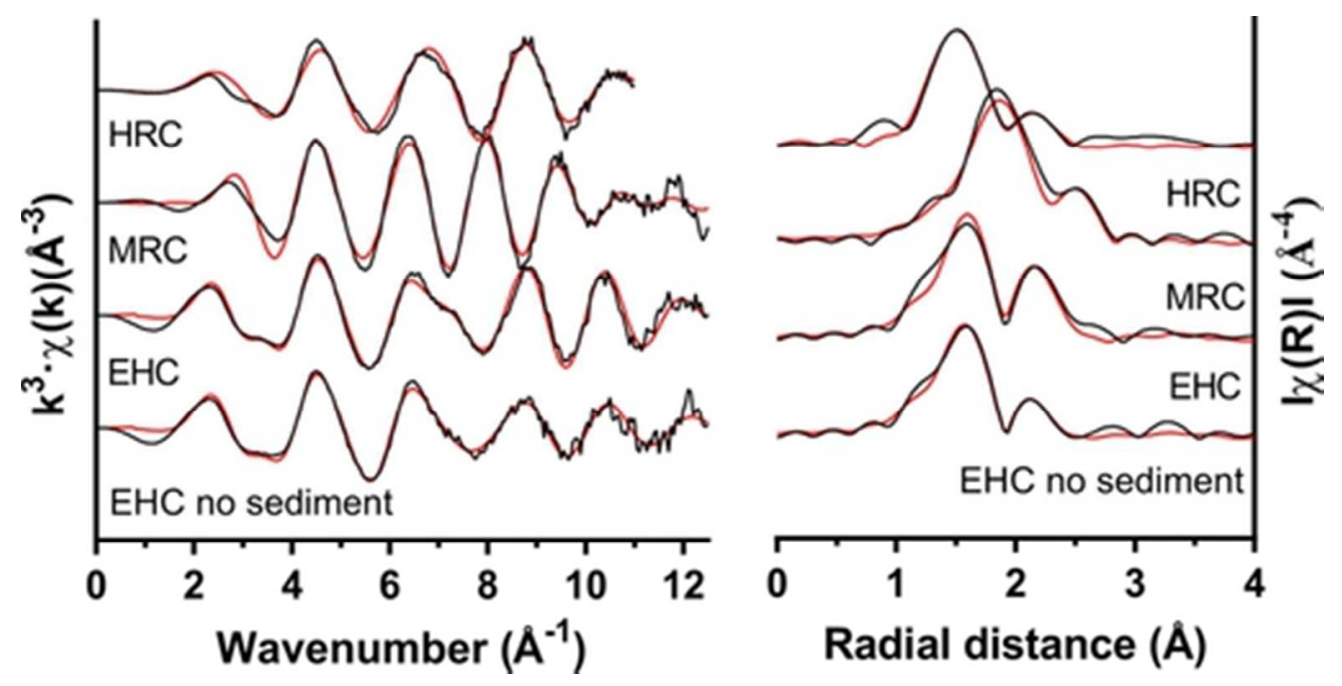

Figure 4. Non-phase shift corrected EXAFS data (black) and fits (red) for sediments biostimulated with HRC, MRC and EHC and for EHC with no sediment; fits are presented in Table S4.

$42 \times 21 \mathrm{~mm}(300 \times 300 \mathrm{DPI})$ 

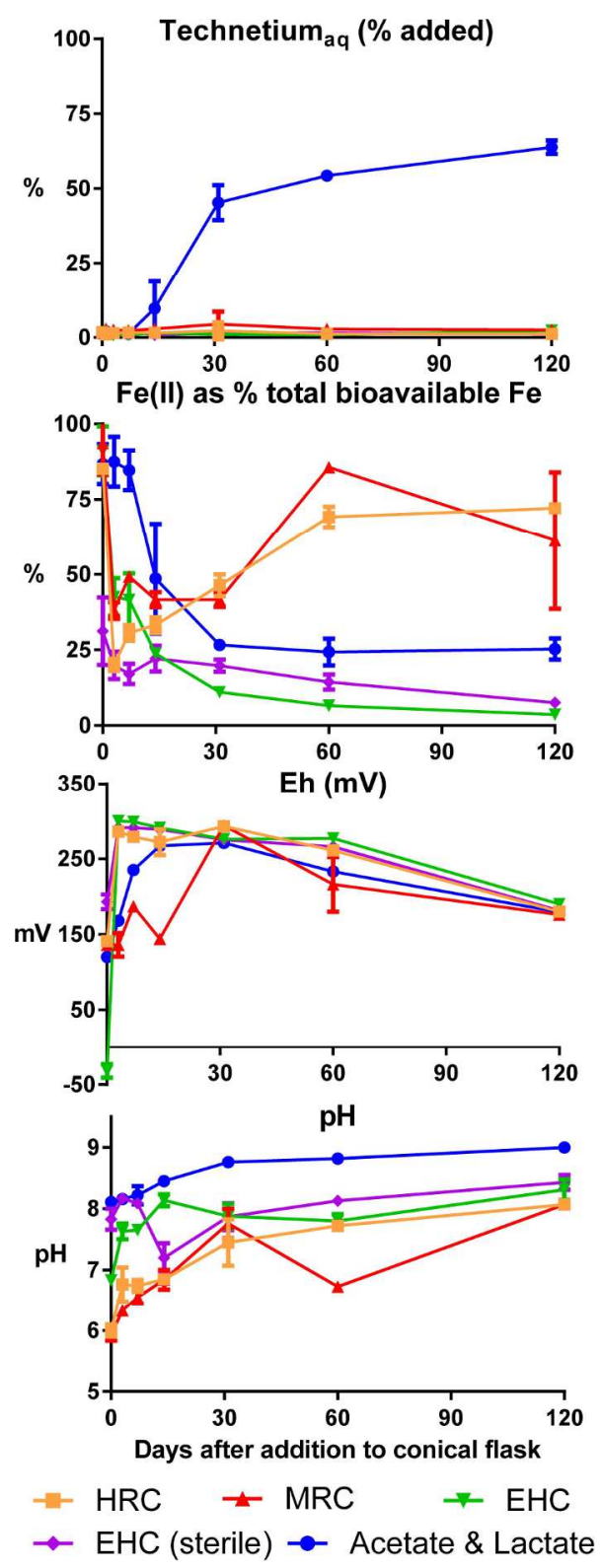

Figure 5. Reoxidation geochemistry for the low-level sediment microcosms. The Tc(IV) that had been formed by biostimulation with slow-release electron donors was recalcitrant to oxidative remobilisation, unlike with acetate and lactate (blue lines).

$211 \times 561 \mathrm{~mm}(300 \times 300 \mathrm{DPI})$ 


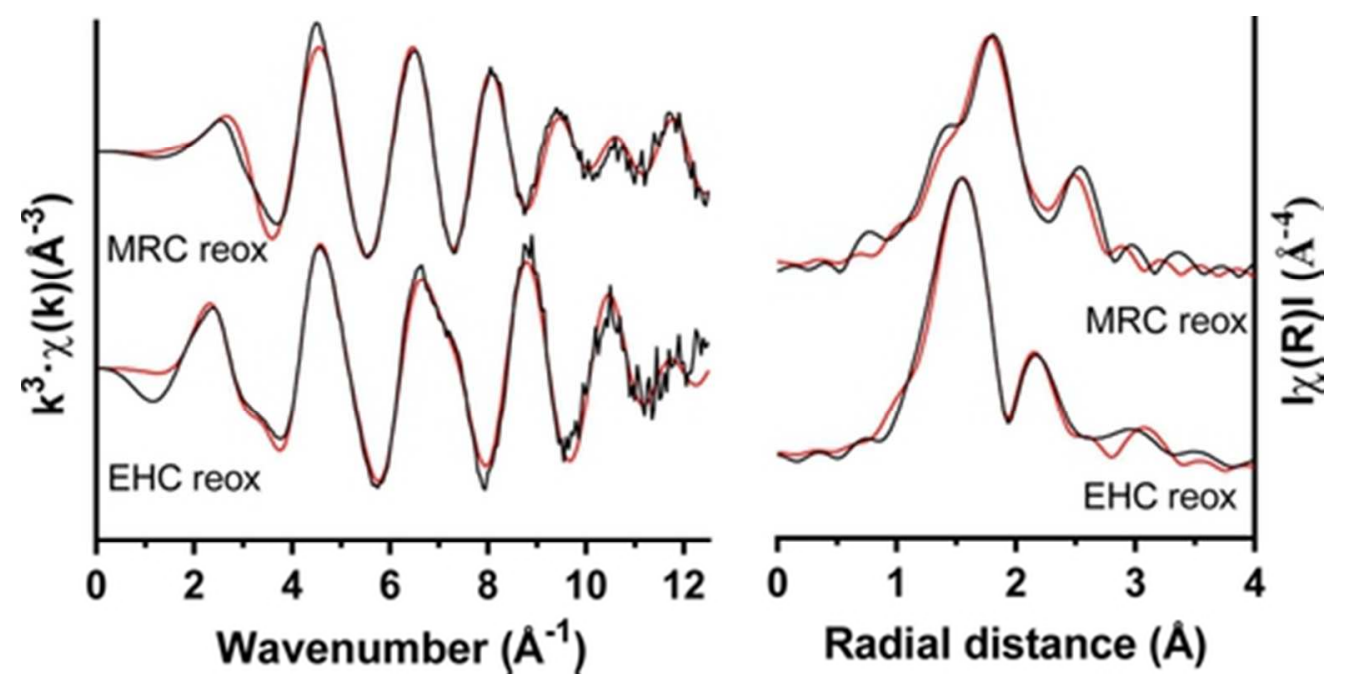

Figure 6 Non-phase shift corrected EXAFS data (black) and fits (red) for sediments biostimulated with MRC and $\mathrm{EHC}$ and then reoxidised in air. Fits are presented in Table S6.

$42 \times 21 \mathrm{~mm}(300 \times 300 \mathrm{DPI})$ 


\title{
Long-term immobilization of technetium via
}

\section{bioremediation with slow-release substrates}

\author{
Laura Newsome ${ }^{1 *}$, Adrian Cleary ${ }^{1}$, Katherine Morris ${ }^{1}$, Jonathan R Lloyd ${ }^{1}$ \\ ${ }^{1}$ Williamson Research Centre and Research Centre for Radwaste Disposal, School of Earth, \\ Atmospheric and Environmental Sciences, Williamson Building, Oxford Road, Manchester, \\ M13 9PL, UK
}

* L. Newsome. Email: laura.newsome@,manchester.ac.uk. Phone: +44 (0)161 2750309.

Submitted to Environmental Science \& Technology

Number of Pages: 20

Number of Tables: 6 (Table S1 - S6)

Number of Figures: 9 (Figure S1 - S9) 


\section{Discussion of $\mathrm{Te}(\mathrm{VII})$ reduction rates at different $\mathrm{Te}$ concentrations}

In our low level experiments with $\mathrm{HRC}, \mathrm{MRC}$ and $\mathrm{EHC}\left(0.1 \mathrm{kBq} \mathrm{ml}^{-1}, 1.6 \mu \mathrm{M}\right.$ Tc in the reduction experiments, $0.12 \mathrm{kBq} \mathrm{ml}^{-1}, 1.9 \mu \mathrm{M}$ Tc in the reoxidation experiments ${ }^{1}$ ), almost all $\mathrm{Tc}(\mathrm{VII})$ was removed from solution within 90 days (Figure 1 main manuscript). $\mathrm{Tc}_{\mathrm{aq}}$ removal was observed to be slower in the higher Tc(VII) concentration XAS experiments $\left(20 \mathrm{kBq} \mathrm{ml}^{-}\right.$ $1,320 \mu \mathrm{M}$ in the reduction experiments, $25 \mathrm{kBq} \mathrm{ml}^{-1}, 400 \mu \mathrm{M}$ in the reoxidation experiments), particularly in the high Tc HRC experiment where considerable quantities of Tc(VII) remained in solution after 139 days (Figure 2 main manuscript), but also to some extent in the time it took for $\mathrm{Tc}_{\mathrm{aq}}$ removal in the high level MRC experiment. This effect has been observed previously e.g. by Burke et al. (2005). Possible explanations for this could be that: (a) Tc(VII) reduction was limited by the amount of bioavailable Fe(III) present, such as observed by Wildung et al. (2004); or (b) that the elevated Tc concentrations were toxic and so inhibited the activity of sediment bacteria.

(a) In terms of $0.5 \mathrm{~N}$ hydroxylamine-hydrochloride extractable "bioavailable" Fe(III) in the elevated Tc experiments, there was considerably less present in the HRC system at Day 139 compared to MRC and EHC (see table below), and certainly not enough to supply the electron demand to reduce $0.4 \mathrm{mM}$ of Tc(VII) via a three electron transfer. Therefore it seems likely that $\mathrm{Tc}(\mathrm{VII})$ reduction may have been inhibited at elevated $\mathrm{Tc}(\mathrm{VII})$ concentrations due to limited amounts of microbial Fe(II) to drive the reduction.

Stoichiometry of Tc and Fe in the elevated Tc XAS reoxidation experiments at Day 139

\begin{tabular}{|c|c|c|c|c|c|c|}
\hline Treatment & $\begin{array}{c}{ }^{99} \mathrm{Te}(\mathrm{VII}) \\
\text { added } \\
(\mathrm{mM})\end{array}$ & $\begin{array}{l}{ }^{99} \mathrm{Tc} \text { on } \\
\text { solid if fully } \\
\text { reduced } \\
(\mathrm{mM})\end{array}$ & $\begin{array}{l}\mathrm{Fe}(\mathrm{II}) \text { in } \\
\text { slurry* } \\
(\mathrm{mM})\end{array}$ & $\begin{array}{c}\text { Fe(total } \\
\text { bioavailable) } \\
\text { in slurry } \\
\text { (mM) }\end{array}$ & $\begin{array}{c}\text { Fe(total } \\
\text { bioavailable) } \\
\text { in sediment } \\
(\mathrm{mM})\end{array}$ & $\begin{array}{l}\mathrm{Fe}(\mathrm{II}) / \\
\mathrm{Te}(\mathrm{VII})\end{array}$ \\
\hline HRC@ & \multirow{3}{*}{0.4} & \multirow{3}{*}{5.7} & 0.56 & 0.87 & 12 & 1.4 \\
\hline MRC@ & & & 2.1 & 2.2 & 32 & 5.3 \\
\hline ЕHC® & & & 4.45 & 7.6 & 108 & 11 \\
\hline
\end{tabular}

* Some of the $\mathrm{Fe}(\mathrm{II})$ will be present in the aqueous phase therefore it is not possible to estimate $\mathrm{Fe}(\mathrm{II})$ in sediment

Wildung et al. (2004) found that $\mathrm{Fe}(\mathrm{II}) / \mathrm{Tc}(\mathrm{VII})$ values greater than 4.3 were sufficient to reduce $>80 \%$ of the $\mathrm{Tc}(\mathrm{VII})$ whereas most sediments with $\mathrm{Fe}(\mathrm{II}) / \mathrm{Tc}(\mathrm{VII})$ less than 1.1 reduced less than $20 \% \mathrm{Tc}(\mathrm{VII})$. The $\mathrm{Fe}(\mathrm{II}) / \mathrm{Tc}(\mathrm{VII})$ in our HRC experiment was 1.4 , which may be too low to drive $\mathrm{Tc}(\mathrm{VII})$ reduction.

(b) To further investigate whether the toxicity effects of high concentrations of Tc, an aliquot of sediment slurry $(0.5 \mathrm{ml})$ was taken from each high level experiment after 139 days and added to $100 \mathrm{ml}$ freshwater minimal medium with $20 \mathrm{mM}$ nitrate or $20 \mathrm{mM}$ ferrihydrite as the electron acceptors and $10 \mathrm{mM}$ acetate as the electron donor. In this subsequent experiment the Tc concentrations was diluted to $125 \mathrm{~Bq} / \mathrm{ml}$. Results showed

\footnotetext{
${ }^{1}$ the different concentrations were due to a different stock solution being used
} 
that the inoculum from each high level experiment was capable of both nitrate and $\mathrm{Fe}(\mathrm{III})$-reduction in the minimal medium. This suggests that exposure to high levels of Tc did not sterilise the sediments, although it is possible the Tc(VII) may have inhibited the sediment microbial community to some extent.

Therefore in summary, the rate of $\mathrm{Tc}(\mathrm{VII})$ reduction in the HRC system may have been limited by the low amounts of $\mathrm{Fe}(\mathrm{II})$ to drive the reaction. In both the HRC and MRC systems microbial Fe(III)-reduction may have been slower due to toxicity effects from the high Tc concentrations. Tc(VII) reduction was not slower in the EHC system, which presumably was driven by chemical reduction at these higher Tc concentrations.

Burke, I. T.; Boothman, C.; Lloyd, J. R.; Livens, F. R.; Charnock, J. M.; McBeth, J. M.; Mortimer, R. J. G.; Morris, K. Reoxidation behavior of technetium, iron, and sulfur in estuarine sediments. Environ. Sci. Technol. 2006, 40, 3529-3535.

Wildung, R. E.; Li, S. W.; Murray, C. J.; Krupka, K. M.; Xie, Y.; Hess, N. J.; Roden, E. E. Technetium reduction in sediments of a shallow aquifer exhibiting dissimilatory iron reduction potential. FEMS Microbiol. Ecol. 2004, 49, 151-162. 


\section{Supporting Tables}

Table S1. Details of slow-release electron donors. All are suitable for direct injection to the subsurface to treat contaminated groundwater; certain formulations of EHC ${ }^{\circledR}$ are also suitable for deployment in permeable reactive barriers

\begin{tabular}{|c|c|c|c|c|}
\hline $\begin{array}{l}\text { Slow- } \\
\text { release } \\
\text { donor }\end{array}$ & Details & $\begin{array}{l}\text { Previously } \\
\text { used for }\end{array}$ & $\begin{array}{l}\text { Selected for use here } \\
\text { because }\end{array}$ & Reference \\
\hline $\begin{array}{l}\text { Hydrogen } \\
\text { Release } \\
\text { Compound } \AA \\
(\text { HRC } \AA)\end{array}$ & $\begin{array}{l}\text { A glycerol tripoly-lactate } \\
\text { compound that is designed } \\
\text { to degrade slowly in } \\
\text { groundwater to generate } \\
\text { lactic acid over a prolonged } \\
\text { time period. Lactic acid is } \\
\text { then fermented by anaerobic } \\
\text { microbes to release } \\
\text { hydrogen which acts as an } \\
\text { electron donor }\end{array}$ & $\begin{array}{l}\text { Reductive } \\
\text { dechlorination } \\
\text { of chlorinated } \\
\text { solvents }\end{array}$ & $\begin{array}{l}\text { As a standard slow- } \\
\text { release substrate that has } \\
\text { widely been used in the } \\
\text { subsurface. Potentially } \\
\text { may stimulate the } \\
\text { reductive precipitation of } \\
\mathrm{TcO}_{2} \text {, sulfate-reducing } \\
\text { bacteria, or even direct } \\
\text { Tc(VII) reduction via } \\
\text { hydrogenases }\end{array}$ & $\frac{\text { www.regenesis. }}{\underline{\text { com }}}$ \\
\hline $\begin{array}{l}\text { Metals } \\
\text { Remediation } \\
\text { Compound } \AA \\
(\text { MRC } ®)\end{array}$ & $\begin{array}{l}\text { Similar to HRC@ but also } \\
\text { containing an organosulfur } \\
\text { ester }\end{array}$ & $\begin{array}{l}\text { Direct } \\
\text { microbial } \\
\text { reduction of } \\
\text { Cr(VI) or } \\
\text { indirect } \\
\text { reduction via } \\
\text { microbial } \\
\text { generation of } \\
\text { Fe(II) or } \\
\text { sulfide } \\
\end{array}$ & $\begin{array}{l}\text { Potential to generate } \\
\text { Tc(IV) sulfides }\end{array}$ & $\frac{\text { www.regenesis. }}{\underline{\text { com }}}$ \\
\hline EHC® & $\begin{array}{l}\text { Mixture of micro-scale zero } \\
\text { valent iron }(\sim 40 \%) \text { and } \\
\text { food grade plant matter }(\sim \\
60 \%)\end{array}$ & $\begin{array}{l}\text { Chlorinated } \\
\text { solvents }\end{array}$ & $\begin{array}{l}\text { ZVI content means has } \\
\text { the potential to stimulate } \\
\text { Tc(VII) reduction in } \\
\text { sediments containing } \\
\text { low concentrations of } \\
\text { bioavailable iron (such } \\
\text { as Sellafield sandstone), } \\
\text { can produce } \mathrm{H}_{2} \text { to } \\
\text { stimulate microbial } \\
\text { reduction }\end{array}$ & $\frac{\text { www.peroxych }}{\underline{\text { em.com }}}$ \\
\hline
\end{tabular}


Table S2. Details of molecular ecology sequences

\begin{tabular}{|c|c|c|c|c|}
\hline Sample & $\begin{array}{l}\text { Number } \\
\text { of reads }\end{array}$ & $\begin{array}{c}\text { Number after } \\
\text { quality control, } \\
\text { chimera check \& } \\
\text { denoising }\end{array}$ & $\begin{array}{c}\text { Number of } \\
\text { identified } \\
\text { OTUs }\end{array}$ & $\begin{array}{l}\text { Shannon } \\
\text { diversity at } \\
4,366 \text { reads }\end{array}$ \\
\hline HRC $\AA$ Day 0 & 7,557 & 5,236 & 820 & 8.57 \\
\hline HRC $₫$ Day 90 & 8,382 & 7,162 & 380 & 4.65 \\
\hline MRC $®$ Day 90 & 5,526 & 4,482 & 353 & 6.08 \\
\hline EHC $₫$ Day 90 & 5,964 & 4,662 & 377 & 6.25 \\
\hline EHC® Day 90 Archaea & 5,101 & 4,858 & 85 & 4.34 \\
\hline
\end{tabular}

\section{Rarefaction curves showing sample diversity}

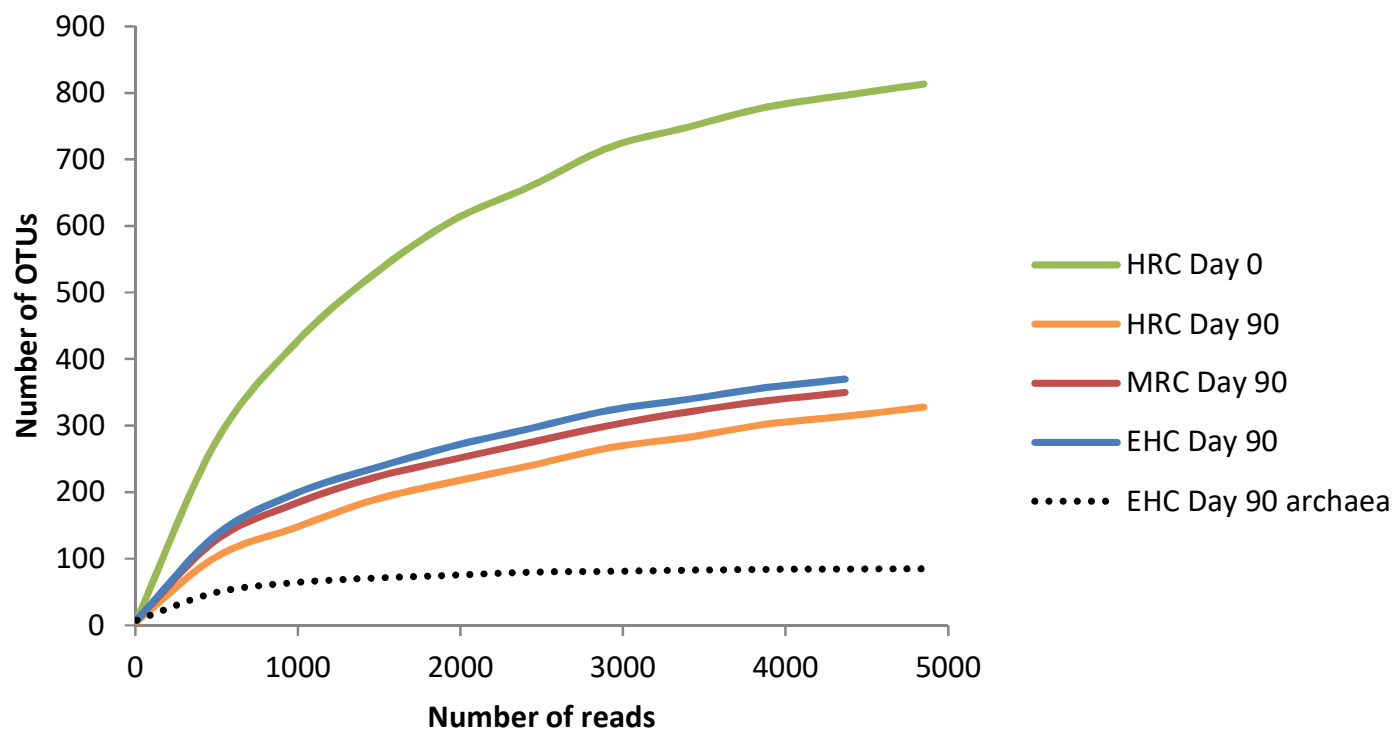


Table S3. Closest phylogenetic relatives of the five most abundant OTUs after biostimulation with slow-release electron donor substrates

\begin{tabular}{|c|c|c|c|c|c|c|c|c|c|}
\hline \multirow[b]{2}{*}{$\begin{array}{l}\text { OTU } \\
\text { ID }\end{array}$} & \multirow[b]{2}{*}{ No. } & \multirow[b]{2}{*}{$\%$} & \multirow[b]{2}{*}{$\begin{array}{l}\text { Classification assignment } \\
\text { (consensus lineage) }\end{array}$} & \multirow[b]{2}{*}{ Family } & \multicolumn{5}{|c|}{ Closest phylogenetic relative } \\
\hline & & & & & Name & $\begin{array}{l}\text { Accession } \\
\text { Number }\end{array}$ & $\begin{array}{l}\text { \% ID } \\
\text { similarity } \\
(\max )\end{array}$ & $\begin{array}{l}\text { Score } \\
(\max )\end{array}$ & Description \\
\hline \multicolumn{10}{|c|}{ HRC® Day 0 bacteria } \\
\hline 25 & 156 & 3.0 & $\begin{array}{l}\text { k_Bacteria;p_Proteobacteria;c_Beta } \\
\text { proteobacteria;o__Methylophilales;f__ } \\
\text { Methylophilaceae }\end{array}$ & Methylophilaceae & $\begin{array}{l}\text { Uncultured } \\
\text { Methylophilus sp. } \\
\text { clone Me60A10 }\end{array}$ & GU472577.1 & $98(98)$ & $\begin{array}{c}1049 \\
(1108)\end{array}$ & $\begin{array}{l}\text { Sulfur cycle prokaryotes in low-sulfate lake. Similar results for } \\
\text { aerobic methanotrophs, methylotrophs (Methylotenera versatilis } \\
\text { strain 301,NR_074693.1,96\% similarity), methane consumption } \\
\text { Arctic lakes }\end{array}$ \\
\hline 23 & 113 & 2.2 & $\begin{array}{l}\text { k_Bacteria;p_Proteobacteria;c_Beta } \\
\text { proteobacteria;o__Burkholderiales;___C } \\
\text { omamonadaceae }\end{array}$ & Comamonadaceae & Ideonella sp. 201-F6 & LC002525.1 & $99(99)$ & $\begin{array}{l}955 \\
(955)\end{array}$ & $\begin{array}{l}\text { PET degrading consortium. Similar results for elevated } \mathrm{CO}_{2} \text {, } \\
\text { weathered sandstone, rice paddy soils, biofilm reactor }\end{array}$ \\
\hline 31 & 95 & 1.8 & $\begin{array}{l}\text { k_Bacteria;p_Proteobacteria;c_Beta } \\
\text { proteobacteria;o_Burkholderiales;f_C } \\
\text { omamonadaceae;g_Polaromonas;s__ }\end{array}$ & Comamonadaceae & $\begin{array}{l}\text { Polaromonas sp. } \\
\text { H8N }\end{array}$ & KU586657.1 & $99(99)$ & $\begin{array}{l}897 \\
(910)\end{array}$ & $\begin{array}{l}\text { Arctic \& Antarctic glacial surfaces. Similar results for anaerobic } \\
\text { digestor, landfill leachate, rhizosphere, river water }\end{array}$ \\
\hline 38 & 94 & 1.8 & $\begin{array}{l}\text { k_Bacteria;p_Nitrospirae;c_Nitrospi } \\
\text { ra;o_Nitrospirales;f_Nitrospiraceae;g } \\
\text { _Nitrospira;s__ }\end{array}$ & Nitrospiraceae & $\begin{array}{l}\text { Uncultured } \\
\text { Nitrospira sp. clone } \\
\text { Nsp1 16S }\end{array}$ & AY876621.1 & $99(99)$ & $\begin{array}{l}782 \\
(782)\end{array}$ & $\begin{array}{l}\text { Uncultured bacterium from study of nitrite oxidising community } \\
\text { in grassland soils. Similar results for tufa, rhizosphere, methane } \\
\text { emitting soils, permafrost, red mud, nitrite-oxidising bioreactor } \\
\text { (Nitrospira sp. strain GC86, Y14644.1, 96\% similarity) }\end{array}$ \\
\hline 40 & 89 & 1.7 & $\begin{array}{l}\text { k_Bacteria;p_Proteobacteria;c_Beta } \\
\text { proteobacteria;o__MND1;f_;g_;s_- }\end{array}$ & & $\begin{array}{l}\text { Uncultured } \\
\text { bacterium clone } \\
\text { CL71 } 16 \mathrm{~S}\end{array}$ & KF247866.1 & $99(99)$ & $\begin{array}{c}1099 \\
(1099)\end{array}$ & $\begin{array}{l}\text { Uncultured bacterium from wetland sediments. Similar results } \\
\text { for methane emitting soils, peat soil methanotrophs, river } \\
\text { sediment, rhizosphere, rice paddy soils }\end{array}$ \\
\hline \multicolumn{10}{|c|}{ HRC $®$ Day 90 bacteria } \\
\hline 0 & 3062 & 42.8 & $\begin{array}{l}\text { k_Bacteria;p__Tenericutes;c__Mollicu } \\
\text { tes;___RF39;f_;g_;s__ }\end{array}$ & & $\begin{array}{l}\text { Uncultured } \\
\text { bacterium clone } \\
\text { D14R15C106 }\end{array}$ & FM956796.1 & $99(99)$ & $\begin{array}{c}969 \\
(969)\end{array}$ & $\begin{array}{l}\text { Uncultured bacterium from rice field soil. Similar results for soil } \\
\text { bacterial interactions with iron oxides, anaerobic digestor }\end{array}$ \\
\hline 97 & 478 & 6.7 & $\begin{array}{l}\text { k_Bacteria;p_Tenericutes;c__Mollicu } \\
\text { tes;o_RF39;f_;g__;__ }\end{array}$ & & $\begin{array}{l}\text { Uncultured } \\
\text { bacterium clone } \\
\text { D14R15C106 }\end{array}$ & FM956796.1 & $99(99)$ & $\begin{array}{c}1068 \\
(1068)\end{array}$ & $\begin{array}{l}\text { Uncultured bacterium from rice field soil. Similar results for } \\
\text { anaerobic digesters }\end{array}$ \\
\hline 16 & 209 & 2.9 & $\begin{array}{l}\text { k_Bacteria;p_Firmicutes;c_Clostridi } \\
\text { a;o_Clostridiales;f_Veillonellaceae;g } \\
\text { __Pelosinus;s__ }\end{array}$ & Veillonellaceae & $\begin{array}{l}\text { Psychrosinus } \\
\text { fermentans strain } \\
\text { FCF9 }\end{array}$ & NR_115860.1 & $96(96)$ & $\begin{array}{c}818 \\
(848)\end{array}$ & $\begin{array}{l}\text { Lactate fermenting bacterium from Antarctic lake. Similar results } \\
\text { for metal-reducing Pelosinus UF01 (DQ295866.1, 95\% } \\
\text { similarity), a lactate utilising population under Fe(III)-reducing } \\
\text { conditions in rice field soil, uranium bioreduction }\end{array}$ \\
\hline 8 & 197 & 2.8 & $\begin{array}{l}\text { k_Bacteria;p_Bacteroidetes;c_Flavo } \\
\text { bacteriia;o_Flavobacteriales; } ; \text { _Flavob } \\
\text { acteriaceae;g_Flavobacterium }\end{array}$ & Flavobacteriaceae & $\begin{array}{l}\text { Flavobacterium sp. } \\
\text { WB2.3-63 }\end{array}$ & AM934649.1 & $98(98)$ & $\begin{array}{c}708 \\
(708)\end{array}$ & $\begin{array}{l}\text { Study of influence of aerobic heterotrophs on forest soil } \\
\text { communities, also study of hard-water rivulet. Similar results for } \\
\text { acetate amended subsurface, lake sediments }\end{array}$ \\
\hline 141 & 193 & 2.7 & $\begin{array}{l}\text { k__Bacteria;p_Proteobacteria;c__Gam } \\
\text { maproteobacteria;o_Pseudomonadales; } \\
\text { f_Pseudomonadaceae;g_Pseudomona } \\
\text { s;s__ }\end{array}$ & Pseudomonadaceae & $\begin{array}{l}\text { Pseudomonas sp. } \\
\text { type strain HMPB4 }\end{array}$ & AM746975.1 & $99(99)$ & $\begin{array}{c}870 \\
(877)\end{array}$ & $\begin{array}{l}\text { Psychrotropic bacteria. Similar results for Antarctic / glacial / } \\
\text { permafrost } P \text {. mandelli, humic degraders, elevated } \mathrm{CO}_{2} \text { soils, } P \text {. } \\
\text { syringae, P. frederiksbergensis (NR_117177.1 and } \\
\text { NR_028906.1), coal gasification site }\end{array}$ \\
\hline
\end{tabular}




\begin{tabular}{|c|c|c|c|c|c|c|c|c|c|}
\hline \multirow[b]{2}{*}{$\begin{array}{l}\text { OTU } \\
\text { ID }\end{array}$} & \multirow[b]{2}{*}{ No. } & \multirow[b]{2}{*}{$\%$} & \multirow[b]{2}{*}{$\begin{array}{l}\text { Classification assignment } \\
\text { (consensus lineage) }\end{array}$} & \multirow[b]{2}{*}{ Family } & \multicolumn{5}{|c|}{ Closest phylogenetic relative } \\
\hline & & & & & Name & $\begin{array}{l}\text { Accession } \\
\text { Number }\end{array}$ & $\begin{array}{l}\text { \% ID } \\
\text { similarity } \\
(\max )\end{array}$ & $\begin{array}{l}\text { Score } \\
(\max )\end{array}$ & Description \\
\hline \multicolumn{10}{|c|}{ MRC® Day 90 bacteria } \\
\hline 3 & 565 & 12.6 & $\begin{array}{l}\text { k_Bacteria;p_Firmicutes;c_Clostridi } \\
\text { a;o_Clostridiales;f_Ruminococcaceae } \\
\text {;g_Ruminococcus;s }\end{array}$ & Ruminococcaceae & $\begin{array}{l}\text { Bacterium Irt-JG1- } \\
\quad 53\end{array}$ & AJ295665.1 & $99(99)$ & $\begin{array}{c}1038 \\
(1038)\end{array}$ & $\begin{array}{l}\text { Bacteria in uranium waste mining piles. Similar results from hot } \\
\text { springs, anaerobic biocathodes, onion degrading bacteria, } \\
\text { rhizosphere }\end{array}$ \\
\hline 6 & 449 & 10.0 & $\begin{array}{l}\text { k__Bacteria;p_Firmicutes;c_Clostridi } \\
\text { a;o__Clostridiales;f_Ruminococcaceae }\end{array}$ & Ruminococcaceae & $\begin{array}{l}\text { Bacterium Irt-JG1- } \\
53\end{array}$ & AJ295664.1 & $94(94)$ & $\begin{array}{c}825 \\
(825)\end{array}$ & $\begin{array}{l}\text { Bacteria in uranium waste mining piles. Similar results from } \\
\text { rhizosphere, onion degrading bacteria, dehalogenating } \\
\text { enrichment }\end{array}$ \\
\hline 1292 & 251 & 5.6 & $\begin{array}{l}\text { k_Bacteria;p_Firmicutes;c_Clostridi } \\
\text { a;o_Clostridiales;f_Ruminococcaceae } \\
\text {;g_Ruminococcus;s }\end{array}$ & Ruminococcaceae & $\begin{array}{l}\text { Bacterium Irt-JG1- } \\
53\end{array}$ & AJ295664.1 & $99(99)$ & $\begin{array}{l}964 \\
(964)\end{array}$ & $\begin{array}{l}\text { Bacteria in uranium waste mining piles. Similar results from hot } \\
\text { springs, rhizosphere, dehalogenating enrichment }\end{array}$ \\
\hline 141 & 245 & 5.5 & $\begin{array}{l}\text { k_Bacteria;p_Proteobacteria;c_Gam } \\
\text { maproteobacteria;o_Pseudomonadales; } \\
\text { f_Pseudomonadaceae;g_Pseudomona }\end{array}$ & Pseudomonadaceae & $\begin{array}{l}\text { Pseudomonas sp. } \\
\text { type strain HMPB4 }\end{array}$ & AM746975.1 & $99(99)$ & $\begin{array}{c}870 \\
(877)\end{array}$ & $\begin{array}{l}\text { Psychrotropic bacteria. Similar results for Antarctic / glacial / } \\
\text { permafrost } P \text {. mandelli, humic degraders, elevated } \mathrm{CO}_{2} \text { soils, } P \text {. } \\
\text { syringae, } P \text {. frederiksbergensis }\left(\mathrm{NR} \_117177.1 \text { and }\right. \\
\mathrm{NR} \text { 028906.1), coal gasification site }\end{array}$ \\
\hline 613 & 227 & 5.1 & $\begin{array}{l}\text { k_Bacteria;p_Firmicutes;c_Clostridi } \\
\text { a;o_Clostridiales;f_Ruminococcaceae } \\
\text {;g_Ruminococcus;s_ }\end{array}$ & Ruminococcaceae & $\begin{array}{l}\text { Bacterium Irt-JG1- } \\
\quad 53\end{array}$ & AJ295664.1 & $99(99)$ & $\begin{array}{c}957 \\
(957)\end{array}$ & $\begin{array}{l}\text { Bacteria in uranium waste mining piles. Similar results from } \\
\text { rhizosphere, hyper-arid environment, hot springs, onion } \\
\text { degrading bacteria }\end{array}$ \\
\hline \multicolumn{10}{|c|}{ EHC $®$ Day 90 bacteria } \\
\hline 5 & 736 & 15.8 & $\begin{array}{l}\text { k_Bacteria;p_Bacteroidetes;c_Bacte } \\
\text { roidia;o__Bacteroidales;___BA008;g_; } \\
\text { s__ }\end{array}$ & BA008 & $\begin{array}{l}\text { Uncultured } \\
\text { bacterium clone } \\
\text { t30d34L46 }\end{array}$ & FM956231 & $98(98)$ & $\begin{array}{c}650 \\
(650)\end{array}$ & $\begin{array}{l}\text { Uncultured bacterium from study of syntrophic oxidation of } \\
\text { propionate under methanogenic conditions in rice field soil. } \\
\text { Similar results for rice paddy soils, soil bacterial interactions with } \\
\text { iron oxides }\end{array}$ \\
\hline 9 & 306 & 6.6 & $\begin{array}{l}\text { k_Bacteria;p_Bacteroidetes;c_Bacte } \\
\text { roidia;o__Bacteroidales;___BA008;g_; } \\
\text { s__ }\end{array}$ & BA008 & $\begin{array}{l}\text { Uncultured } \\
\text { Bacteroidetes } \\
\text { bacterium clone } \\
\text { BEMB12B-2H1 }\end{array}$ & KJ955693.1 & $96(97)$ & $\begin{array}{c}821 \\
(834)\end{array}$ & $\begin{array}{l}\text { Uncultured bacterium from a hydrocarbon contaminated site. } \\
\text { Similar results from pristine aquifer, bioremediation of } \\
\text { hydrocarbon \& chlorinated solvents, coal tar DNAPL, phenol } \\
\text { contaminated aquifer }\end{array}$ \\
\hline 150 & 260 & 5.6 & $\begin{array}{l}\text { k_Bacteria;p_Bacteroidetes;c_Bacte } \\
\text { roidia;o__Bacteroidales;___BA008;g_; } \\
\text { s__ }\end{array}$ & BA008 & $\begin{array}{l}\text { Uncultured } \\
\text { Bacteroidetes } \\
\text { bacterium clone } \\
\text { BEMB11B-2B1 }\end{array}$ & KJ955674.1 & $97(97)$ & $\begin{array}{c}805 \\
(810)\end{array}$ & $\begin{array}{l}\text { Uncultured bacterium from a hydrocarbon contaminated site. } \\
\text { Similar results from pristine aquifer, bioremediation of } \\
\text { hydrocarbon \& chlorinated solvents, fuel oil degrading sediments }\end{array}$ \\
\hline 10 & 202 & 4.3 & $\begin{array}{l}\text { k_Bacteria;p_Bacteroidetes;c_Bacte } \\
\text { roidia;o__Bacteroidales;__; __; _ _ }\end{array}$ & & $\begin{array}{l}\text { Uncultured } \\
\text { bacterium clone } \\
\text { BProP7A06 }\end{array}$ & LK024884.2 & $97(98)$ & $\begin{array}{c}1103 \\
(1126)\end{array}$ & $\begin{array}{l}\text { Uncultured bacterium from study of oxidation of ethanol, } \\
\text { propionate and butyrate in methane emitting soil. Similar results } \\
\text { from iron reducers from As contaminated paddy soil, petroleum } \\
\text { contaminated sediments, biofilm reactor for wastewater } \\
\text { treatment, PCB dechlorination }\end{array}$ \\
\hline 461 & 140 & 3.0 & $\begin{array}{l}\text { k_Bacteria;p_Bacteroidetes;c_Bacte } \\
\text { roidia;___Bacteroidales;f_BA008;g_; } \\
\text { s__ }\end{array}$ & BA008 & $\begin{array}{l}\text { Uncultured } \\
\text { Bacteroidetes } \\
\text { bacterium clone } \\
\text { BEMB12B-2H1 }\end{array}$ & KJ955693.1 & $98(98)$ & $\begin{array}{c}829 \\
(829)\end{array}$ & $\begin{array}{l}\text { Uncultured bacterium from a hydrocarbon contaminated site. } \\
\text { Similar results from pristine aquifer, bioremediation of } \\
\text { hydrocarbon \& chlorinated solvents, coal tar DNAPL, anaerobic } \\
\text { digestor }\end{array}$ \\
\hline
\end{tabular}

\section{Page S7 of S20}




\begin{tabular}{|c|c|c|c|c|c|c|c|c|c|}
\hline \multirow[b]{2}{*}{$\begin{array}{l}\text { OTU } \\
\text { ID }\end{array}$} & \multirow[b]{2}{*}{ No. } & \multirow[b]{2}{*}{$\%$} & \multirow[b]{2}{*}{$\begin{array}{l}\text { Classification assignment } \\
\text { (consensus lineage) }\end{array}$} & \multirow[b]{2}{*}{ Family } & \multicolumn{5}{|c|}{ Closest phylogenetic relative } \\
\hline & & & & & Name & $\begin{array}{l}\text { Accession } \\
\text { Number }\end{array}$ & $\begin{array}{l}\text { \% ID } \\
\text { similarity } \\
(\max )\end{array}$ & $\begin{array}{l}\text { Score } \\
(\max )\end{array}$ & Description \\
\hline \multicolumn{10}{|c|}{ EHC® Day 90 Archaea } \\
\hline 4 & 906 & 18.6 & $\begin{array}{l}\text { k_Archaea;p_Crenarchaeota;c_MC } \\
\text { G;o__pGrfC26;f_;g_;s__ }\end{array}$ & & $\begin{array}{l}\text { Uncultured archaeon } \\
\text { clone L15 }\end{array}$ & KJ424509.1 & $98(98)$ & $\begin{array}{c}1076 \\
(1085)\end{array}$ & $\begin{array}{l}\text { Uncultured archaeon from study of microbial methane formation } \\
\text { in deep aquifers of coal sedimentary basin. Similar results to } \\
\text { mining impacted sediments, acidic red soils, lake sediments. 95\% } \\
\text { similarity to anaerobic methanogenic archaeon ET1-8 (score 800) }\end{array}$ \\
\hline 1 & 817 & 16.8 & $\begin{array}{l}\text { k__Archaea;p_Euryarchaeota;c_Ther } \\
\text { moplasmata;o_E2;f_[Methanomassilii } \\
\text { coccaceae];g__Methanomassiliicoccus;s } \\
\text { _ }\end{array}$ & $\begin{array}{c}\text { Methanomassiliicoc } \\
\text { caceae }\end{array}$ & Archaeon LL37A29 & AJ745146.1 & $97(97)$ & $\begin{array}{c}937 \\
(1003)\end{array}$ & $\begin{array}{l}\text { Rice Cluster III archaea. Similar results to study of cultivating } \\
\text { methanogens from deep aquifers, anaerobic filter system, } \\
\text { anaerobic reactor, wastewater treatment, granular sludge. } 94 \% \\
\text { similarity to Methanomassiliicoccus luminyensis strain B10 } \\
\text { (score 976) }\end{array}$ \\
\hline 7 & 451 & 9.3 & $\begin{array}{l}\text { k_Archaea;p_Crenarchaeota;c_MC } \\
\text { G;o__pGrfC26;f_;g_;s__ }\end{array}$ & & $\begin{array}{l}\text { Uncultured } \\
\text { crenarchaeote clone } \\
\text { EP091-2.90 }\end{array}$ & JF789765.1 & $96(98)$ & $\begin{array}{c}892 \\
(928)\end{array}$ & $\begin{array}{l}\text { Anaerobic metabolism in freshwater wetlands. Similar results for } \\
\text { deep aquifers, sludge, uranium mine tailings, acid mine drainage } \\
\text { system, deep aquifers of coal sedimentary basin. } 95 \% \text { similarity } \\
\text { to anaerobic methanogenic archaeon ET1-10 (score } 713 \text { ) }\end{array}$ \\
\hline 26 & 409 & 8.4 & $\begin{array}{l}\text { k_Archaea;p_Crenarchaeota;c_MC } \\
\text { G;o__pGrfC26;f_;g_;s__ }\end{array}$ & & $\begin{array}{l}\text { Uncultured archaeon } \\
\text { clone L15 }\end{array}$ & KJ424509.1 & $97(97)$ & $\begin{array}{c}874 \\
(883)\end{array}$ & $\begin{array}{l}\text { Uncultured archaeon from study of microbial methane formation } \\
\text { in deep aquifers of coal sedimentary basin. Similar results to } \\
\text { mining impacted sediments, acidic red soils, lake sediments. }\end{array}$ \\
\hline 15 & 280 & 5.8 & $\begin{array}{l}\text { k_Archaea;p_Euryarchaeota;c_Ther } \\
\text { moplasmata;__E2;f_[Methanomassilii } \\
\text { coccaceae];g__Methanomassiliicoccus;s }\end{array}$ & $\begin{array}{l}\text { Methanomassiliicoc } \\
\text { caceae }\end{array}$ & $\begin{array}{l}\text { Methanomassiliicoc } \\
\text { cus luminyensis } \\
\text { strain B10 }\end{array}$ & NR_118098.1 & $96(98)$ & $\begin{array}{c}937 \\
(1002)\end{array}$ & $\begin{array}{l}\text { Methanogenic archaeon from human faeces. Similar results for } \\
\text { lake sediment, anaerobic filter system, anaerobic sludge reactor, } \\
\text { rice paddy field soils }\end{array}$ \\
\hline
\end{tabular}


Table S4. Details of EXAFS fit parameters for the technetium minerals formed after biostimulation with $H R C\left({ }^{\circledR}, M R C \circledR\right.$ and $E H C\left({ }^{\text {a }}\right.$

\begin{tabular}{|c|c|c|c|c|c|c|c|c|c|c|c|}
\hline Sample & Path & $\begin{array}{c}\text { Co- } \\
\text { ordination } \\
\text { number }\end{array}$ & $\begin{array}{c}\text { Atomic } \\
\text { distance } \\
(\AA)\end{array}$ & $\begin{array}{c}\text { Debye- } \\
\text { Waller } \\
\text { factor } \sigma^{2} \\
\left(\AA^{2}\right)\end{array}$ & $\begin{array}{l}\text { Confidence } \\
\text { level of } \\
\text { adding } \\
\text { shell }(\alpha){ }^{b}\end{array}$ & $\begin{array}{c}\text { Energy } \\
\text { shift } \Delta \mathbf{E}_{0} \\
\text { from } \\
\text { calculated } \\
\text { Fermi } \\
\text { level }(\mathrm{eV})\end{array}$ & $\begin{array}{c}\text { Reduced } \\
\chi^{2}\end{array}$ & $\begin{array}{c}\mathbf{R} \\
\text { "goodness } \\
\text { of fit } \\
\text { factor" }\end{array}$ & $\begin{array}{c}\text { Number of } \\
\text { variables / } \\
\text { number of } \\
\text { independent } \\
\text { points }\end{array}$ & $k$ range & $\mathbf{R}$ range \\
\hline $\mathrm{HRC}{ }^{c}$ & $\begin{array}{l}\mathrm{O}_{1} \\
\mathrm{O}_{2} \\
\mathrm{Tc}_{1}\end{array}$ & $\begin{array}{c}1 \\
4.4 \\
1\end{array}$ & $\begin{array}{l}1.65(6) \\
2.01(2) \\
2.58(4)\end{array}$ & $\begin{array}{l}0.010(7) \\
0.005(1) \\
0.010(5)\end{array}$ & $\begin{array}{c}0.92 \\
- \\
1.00\end{array}$ & $0.05 \pm 3.7$ & 839 & 0.014 & $7 / 9.2$ & $3-11$ & $1.15-3.0$ \\
\hline $\mathrm{EHC}^{d}{ }^{d}$ & $\begin{array}{c}\mathrm{O} \\
\mathrm{Tc}_{1} \\
\mathrm{O}-\mathrm{O} \mathrm{MS}\end{array}$ & $\begin{array}{c}6 \\
2.1 \\
6\end{array}$ & $\begin{array}{l}2.05(1) \\
2.54(1) \\
4.11(2)\end{array}$ & $\begin{array}{l}0.005(1) \\
0.008(2) \\
0.010(2)\end{array}$ & $\begin{array}{c}- \\
1.00 \\
0.97\end{array}$ & $2.5 \pm 1.1$ & 243 & 0.016 & $6 / 14.0$ & $3-12.5$ & $1.15-3.5$ \\
\hline $\begin{array}{c}\mathrm{EHC} \AA^{e} \\
\text { no } \\
\text { sediment }\end{array}$ & $\begin{array}{c}\mathrm{O} \\
\mathrm{Tc}_{1} \\
\mathrm{O}-\mathrm{O} \mathrm{MS}\end{array}$ & $\begin{array}{l}6 \\
2 \\
6\end{array}$ & $\begin{array}{l}2.05(1) \\
2.51(1) \\
4.13(2)\end{array}$ & $\begin{array}{c}0.007(0.5) \\
0.013(2) \\
0.014(2)\end{array}$ & $\begin{array}{c}- \\
0.98 \\
1.00\end{array}$ & $2.4 \pm 1.0$ & 63.1 & 0.011 & $5 / 14.0$ & $3-12.5$ & $1.15-3.5$ \\
\hline
\end{tabular}

${ }^{a}$ Numbers in parentheses are the SD on the last decimal place. Additional shells were only included if they improved the fitting parameters with statistical significance. ${ }^{b}$ f-test results, $\alpha>0.99$ statistically improves the fit with 3 sigma confidence, $\alpha>0.95$ with 2 sigma confidence, $\alpha>0.68$ with 1 sigma confidence. Throughout the value of the amplitude factor (S02) was refined using known coordination numbers for the first shell (e.g. Tc-O, N=6) after (Brookshaw et al., 2015) ${ }^{c} \mathrm{~S} 02$ fixed at 1.0. ${ }^{d} \mathrm{~S} 02$ fixed at $0.8 .{ }^{e} \mathrm{~S} 02$ was fixed at 0.9.

\section{References}

Brookshaw, D. R.; Pattrick, R. A. D.; Bots, P.; Law, G. T. W.; Lloyd, J. R.; Mosselmans, J. F. W.; Vaughan, D. J.; Dardenne, K.; Morris, K. Redox interactions of Tc(VII), $\mathrm{U}(\mathrm{VI})$, and $\mathrm{Np}(\mathrm{V})$ with microbially reduced biotite and chlorite. Environ. Sci. Technol. 2015, 49 (22), 13139-13148. 
Table S5. Alternative EXAFS fit parameters for the technetium minerals formed after biostimulation with EHC ${ }^{a}{ }^{a}$

\begin{tabular}{|c|c|c|c|c|c|c|c|c|c|c|c|}
\hline Sample & Path & $\begin{array}{c}\text { Co- } \\
\text { ordination } \\
\text { number }\end{array}$ & $\begin{array}{c}\text { Atomic } \\
\text { distance } \\
(\AA)\end{array}$ & $\begin{array}{c}\text { Debye- } \\
\text { Waller } \\
\text { factor } \sigma^{2} \\
\left(\AA^{2}\right)\end{array}$ & $\begin{array}{c}\text { Confidence } \\
\text { level of } \\
\text { adding shell } \\
(\alpha)^{b}\end{array}$ & $\begin{array}{c}\text { Energy } \\
\text { shift } \Delta \mathbf{E}_{0} \\
\text { from } \\
\text { calculated } \\
\text { Fermi } \\
\text { level }(\mathrm{eV})\end{array}$ & $\begin{array}{c}\text { Reduced } \\
\chi^{2}\end{array}$ & $\begin{array}{c}\text { R } \\
\text { "goodness } \\
\text { of fit } \\
\text { factor" }\end{array}$ & $\begin{array}{c}\text { Number of } \\
\text { variables / } \\
\text { number of } \\
\text { independent } \\
\text { points }\end{array}$ & k range & $R$ range \\
\hline $\begin{array}{l}\mathrm{EHC} \AA \text { as } \\
\text { short chain } \\
\mathrm{TcO}_{2} \text { with } \mathrm{Fe}^{c}\end{array}$ & $\begin{array}{c}\mathrm{O} \\
\mathrm{Tc}_{1} \\
\mathrm{Fe} \\
\mathrm{O}-\mathrm{O} \mathrm{MS}\end{array}$ & $\begin{array}{c}6 \\
1.6 \\
0.5 \\
6\end{array}$ & $\begin{array}{l}2.04(1) \\
2.55(1) \\
2.56(6) \\
4.10(2)\end{array}$ & $\begin{array}{c}0.005(1) \\
0.007(2) \\
0.007^{e} \\
0.011(2)\end{array}$ & $\begin{array}{l}- \\
1.00 \\
0.97 \\
0.99\end{array}$ & $1.2 \pm 1.4$ & 224 & 0.011 & $7 / 14.0$ & $3-12.5$ & $1.15-3.5$ \\
\hline
\end{tabular}

${ }^{a}$ Numbers in parentheses are the SD on the last decimal place. Additional shells were only included if they improved the fitting parameters with statistical significance. ${ }^{b}$ f-test results, $\alpha>0.99$ statistically improves the fit with 3 sigma confidence, $\alpha>0.95$ with 2 sigma confidence, $\alpha>0.68$ with 1 sigma confidence. Throughout the value of the amplitude factor (S02) was refined using known coordination numbers for the first shell (e.g. Tc-O, N=6), after Brookshaw et al. (2015) ${ }^{c} \mathrm{~S} 02$ fixed at 0.8. ${ }^{d} \mathrm{~S} 02$ fixed at 0.9. ${ }^{e}$ The Debye-Waller factor for Tc-Fe was fixed at 0.007, similar to Zachara et al. (2007). ${ }^{f}$ f-test result for adding two additional shells of Tc atoms.

\section{References}

Brookshaw, D. R.; Pattrick, R. A. D.; Bots, P.; Law, G. T. W.; Lloyd, J. R.; Mosselmans, J. F. W.; Vaughan, D. J.; Dardenne, K.; Morris, K. Redox interactions of Tc(VII), $\mathrm{U}(\mathrm{VI})$, and $\mathrm{Np}(\mathrm{V})$ with microbially reduced biotite and chlorite. Environ. Sci. Technol. 2015, 49 (22), $13139-13148$.

Zachara, J. M.; Heald, S. M.; Jeon, B. H.; Kukkadapu, R. K.; Liu, C. X.; McKinley, J. P.; Dohnalkova, A. C.; Moore, D. A. Reduction of pertechnetate Tc(VII) by aqueous $\mathrm{Fe}(\mathrm{II})$ and the nature of solid phase redox products. Geochim. Cosmochim. Acta 2007, 71, 2137-2157. 


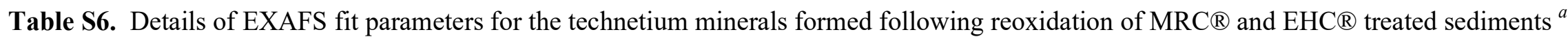

\begin{tabular}{|c|c|c|c|c|c|c|c|c|c|c|c|}
\hline Sample & Path & $\begin{array}{c}\text { Co- } \\
\text { ordination } \\
\text { number }\end{array}$ & $\begin{array}{c}\text { Atomic } \\
\text { distance } \\
(\AA)\end{array}$ & $\begin{array}{c}\text { Debye- } \\
\text { Waller } \\
\text { factor } \sigma^{2} \\
\left(\AA^{2}\right)\end{array}$ & $\begin{array}{c}\text { Confidence } \\
\text { level of } \\
\text { adding shell } \\
(\alpha)^{b}\end{array}$ & $\begin{array}{c}\text { Energy } \\
\text { shift } \Delta \mathbf{E}_{0} \\
\text { from } \\
\text { calculated } \\
\text { Fermi } \\
\text { level }(\mathrm{eV}) \\
\end{array}$ & $\begin{array}{c}\text { Reduced } \\
\chi^{2}\end{array}$ & $\begin{array}{c}\text { R } \\
\text { "goodness } \\
\text { of fit } \\
\text { factor" }\end{array}$ & $\begin{array}{c}\text { Number of } \\
\text { variables / } \\
\text { number of } \\
\text { independent } \\
\text { points }\end{array}$ & k range & $\mathbf{R}$ range \\
\hline $\begin{array}{l}\text { MRC } \\
\text { reoxidised }^{c}\end{array}$ & $\begin{array}{l}\mathrm{S} \\
\mathrm{O} \\
\mathrm{Tc}\end{array}$ & $\begin{array}{l}3.7 \\
2.3 \\
0.5\end{array}$ & $\begin{array}{c}2.34(1) \\
2.05 * \\
2.78(2)\end{array}$ & $\begin{array}{l}0.009(1) \\
0.012(5) \\
0.002(2)\end{array}$ & $\begin{array}{c}- \\
0.99 \\
1.00\end{array}$ & $-0.8 \pm 1.4$ & 687 & 0.017 & $6 / 12.4$ & $3-13$ & $1.15-3.15$ \\
\hline
\end{tabular}

${ }^{a}$ Numbers in parentheses are the SD on the last decimal place. Additional shells were only included if they improved the fitting parameters with statistical significance. ${ }^{b}$ f-test results, $\alpha>0.99$ statistically improves the fit with 3 sigma confidence, $\alpha>0.95$ with 2 sigma confidence, $\alpha>0.68$ with 1 sigma confidence. Throughout the value of the amplitude factor (S02) was refined using known coordination numbers for the first shell (e.g. Tc-O, N=6), after Brookshaw et al. (2015) ${ }^{c} \mathrm{~S} 02$ fixed at 1.0. ${ }^{d} \mathrm{~S} 02$ fixed at 0.9 . The asterisk denotes bond lengths that were fixed based on previous fits from the reduced phase.

\section{References}

Brookshaw, D. R.; Pattrick, R. A. D.; Bots, P.; Law, G. T. W.; Lloyd, J. R.; Mosselmans, J. F. W.; Vaughan, D. J.; Dardenne, K.; Morris, K. Redox interactions of Tc(VII), $\mathrm{U}(\mathrm{VI})$, and $\mathrm{Np}(\mathrm{V})$ with microbially reduced biotite and chlorite. Environ. Sci. Technol. 2015, 49 (22), 13139-13148. 


\section{Supporting Figures}

All geochemical monitoring figures show the average of three replicate measurements and error bars are $+/-1$ standard deviation, unless otherwise stated
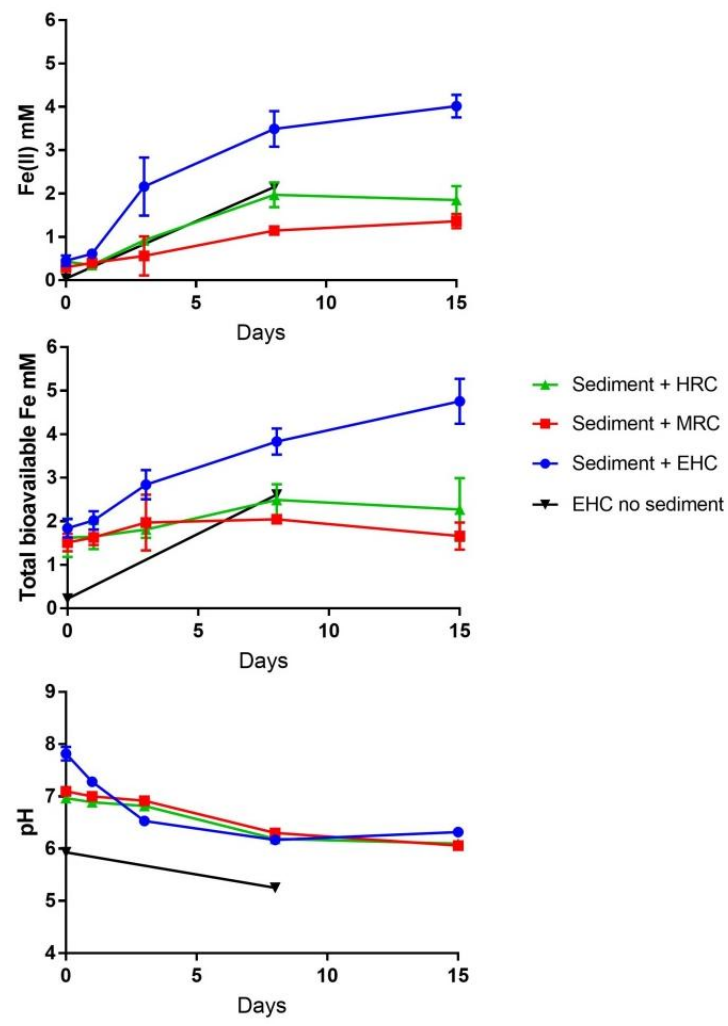

Figure S1a. Slow-release substrates stimulate Fe(III)-reduction in Sellafield sediments and EHC® without sediment was a single measurement and shows that EHC® corrodes abiotically to release $\mathrm{Fe}(\mathrm{II})$.

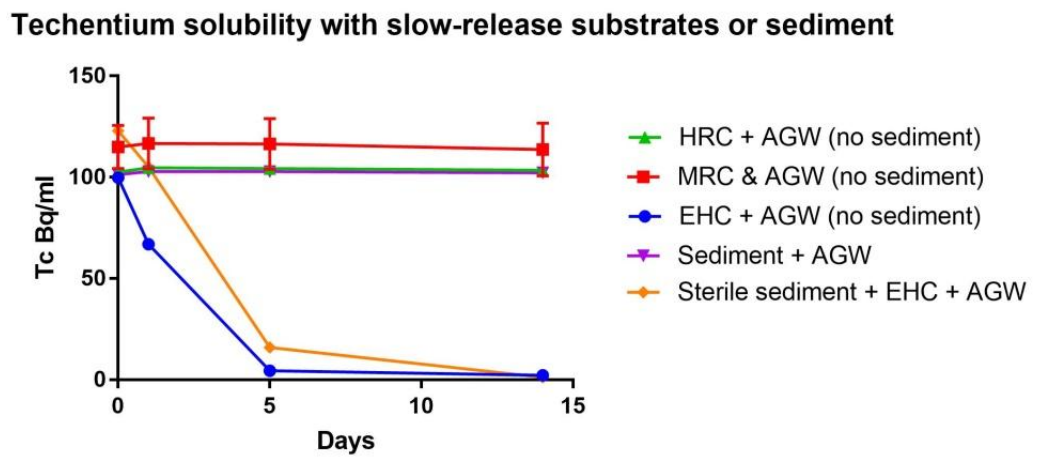

Figure S1b. Solubility tests with the proprietary electron donors. Technetium(VII) remains

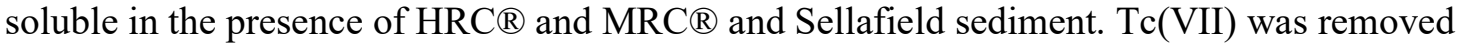
from solution in the presence of EHC® (abiotically). Solubility tests were performed as duplicates, except the sterile sediment which was a single measurement. 
HRC

EHC
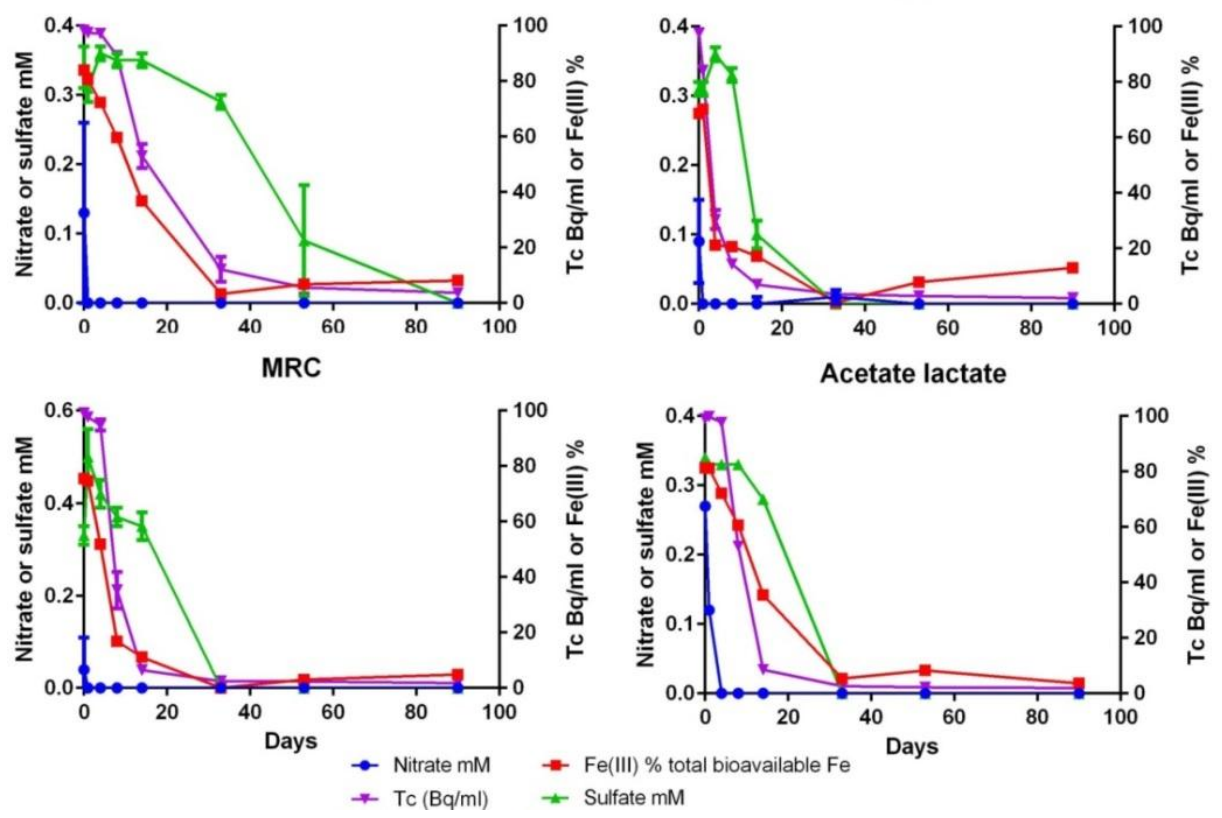

Figure S2. Redox cascade following biostimulation with different slow-release amendments.

The acetate/lactate microcosm was a single positive control. 

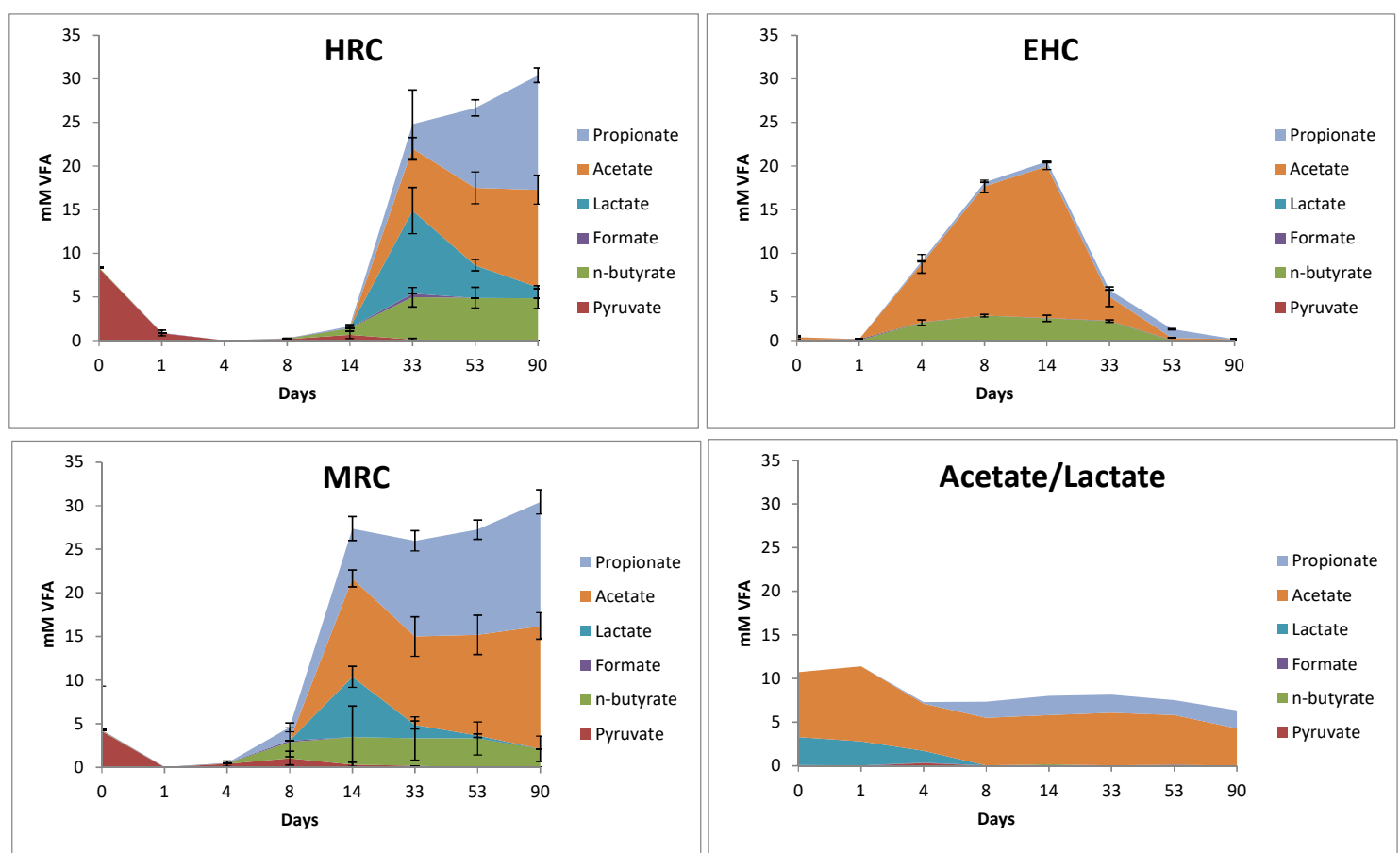

Figure S3. Production of volatile fatty acids following amendments with slow release donors. The acetate/lactate microcosm was a single positive control. Samples were diluted 100 times to ensure correct concentration range for the IC, and complex chromatographs were generated due to the complexity of the biodegradation of the proprietary substances. Data for sterile controls showed that trace VFAs $(<1 \mathrm{mM})$ were present in these samples. 


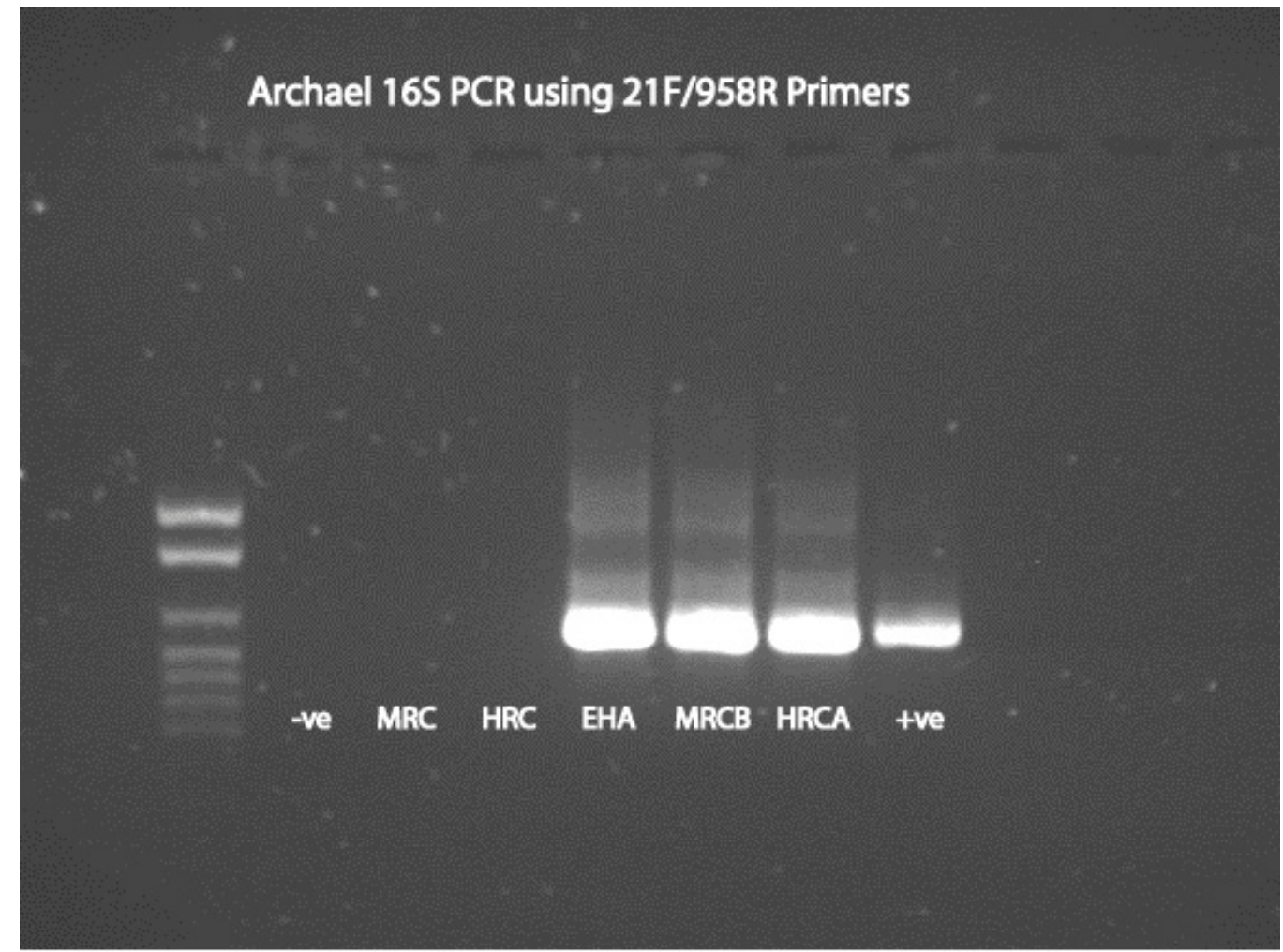

Figure S4. Archaeal PCR products for the MRC® and HRC® substrates, and for the sediment microcosms stimulated with $\mathrm{EHC}{ }^{\circledR}$ ' $\mathrm{EHA}$ ', $\mathrm{MRC}{ }^{\circledR}$ ' $\mathrm{MRCB}$ ' and $\mathrm{HRC}{ }^{\circledR}$ 'HRCA' . Negative and positive controls were also included. 

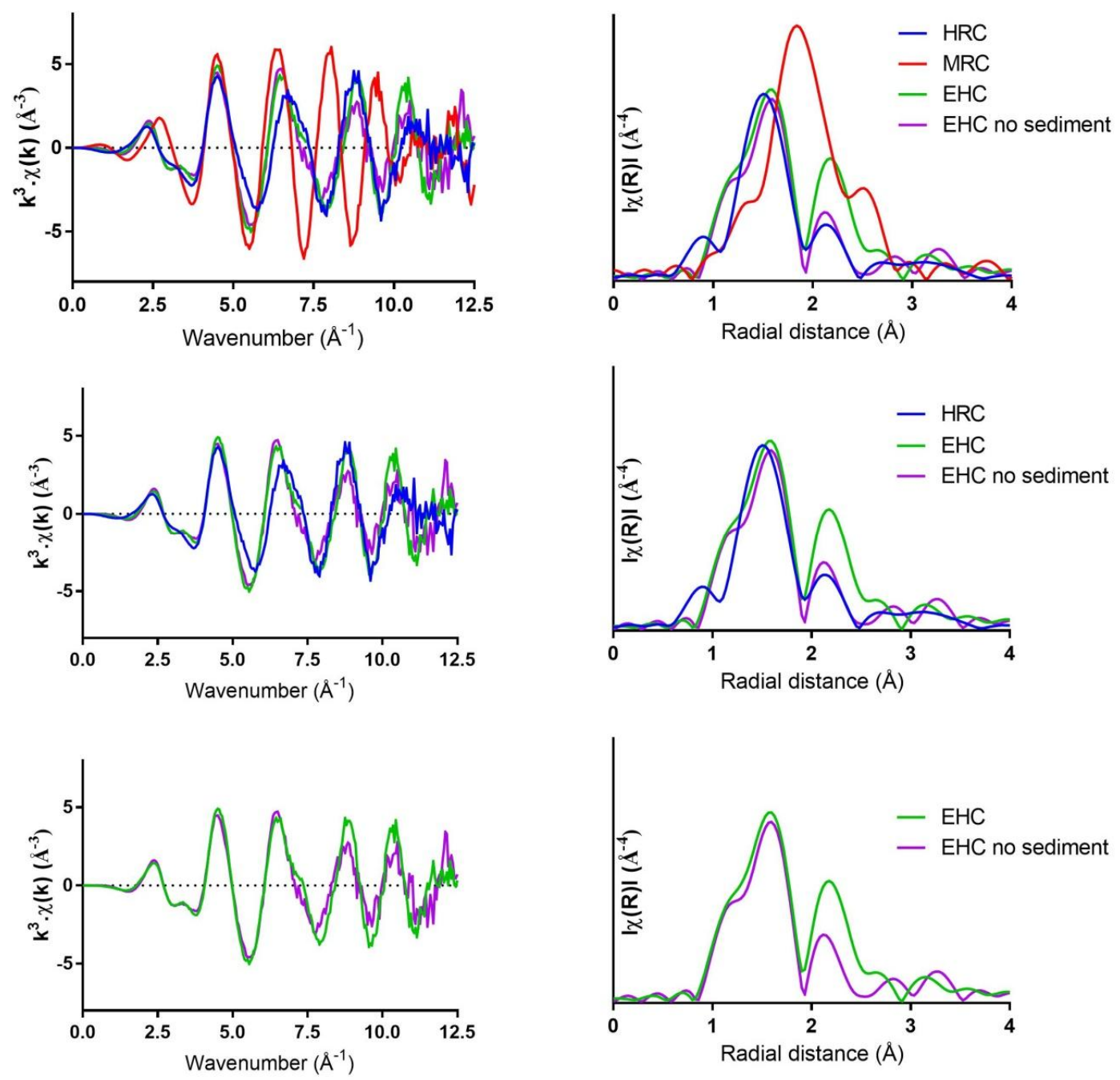

Figure S5. EXAFS data for all samples (top). The Tc(IV) formed by MRC® biostimulation was clearly different to the other samples; this was fitted as $\mathrm{TcS}_{2}$. EXAFS data with MRCR removed for clarity (middle), and with $H R C \circledR$ removed to observe differences in the EHC samples (bottom). The spectra for HRC ${ }^{2}, E H C \circledR$ and $E H C \circledR$ no sediment were all fitted as variants of hydrous $\mathrm{TcO}_{2}$. 

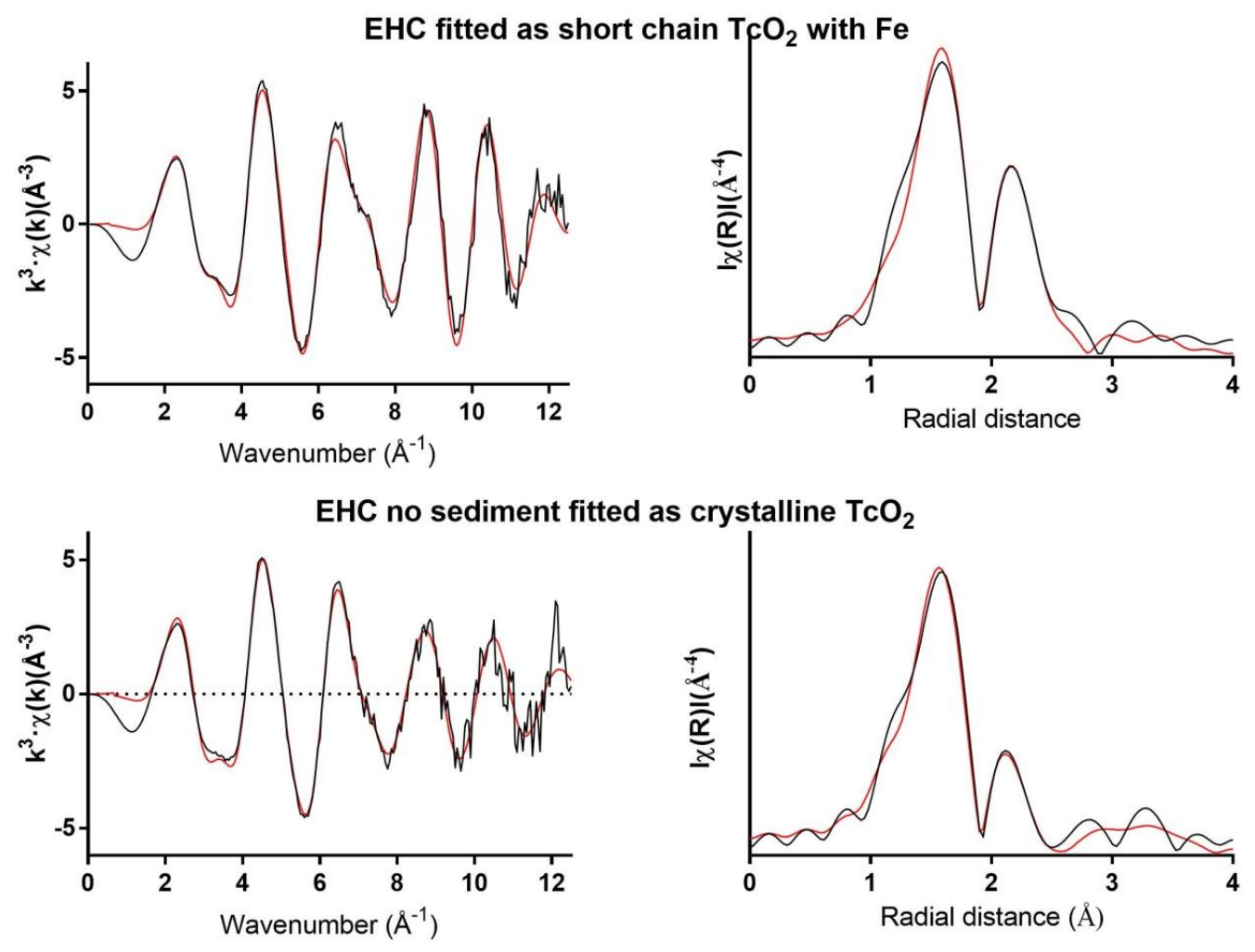

Figure S6. Non-phase shift corrected EXAFS data for sediments biostimulated with EHC ${ }^{\circledR}$ fitted as a short $\mathrm{TcO}_{2}$ chain with $\mathrm{Fe}$ (above) and for $\mathrm{EHC}{ }^{\circledR}$ no sediment fitted as crystalline $\mathrm{TcO}_{2}$ (below). 
HRC

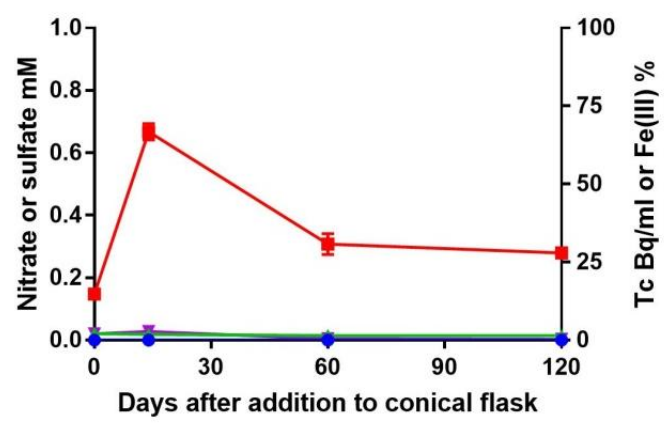

MRC

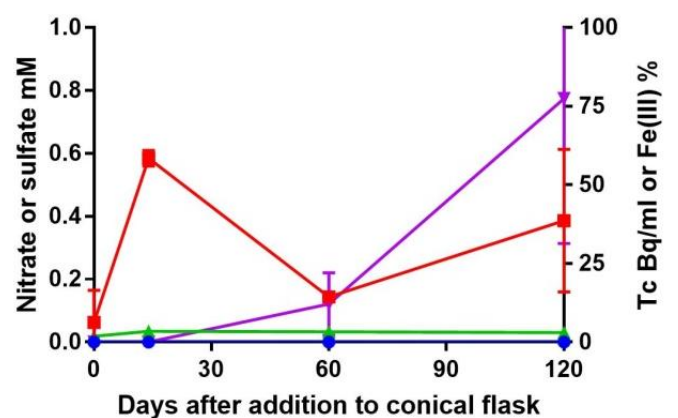

Days after addition to conical flask

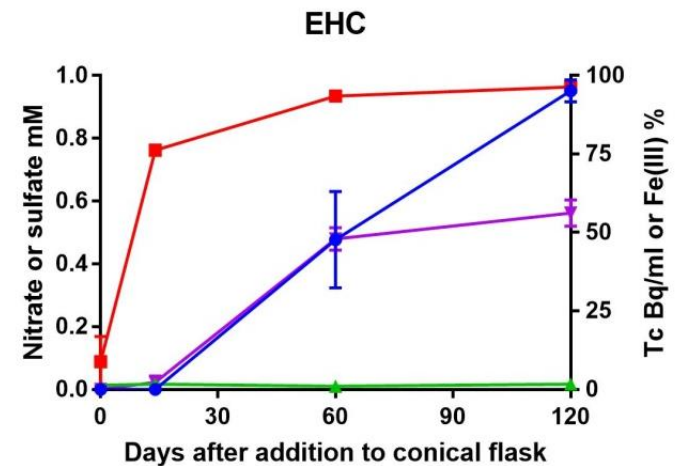

Acetate lactate

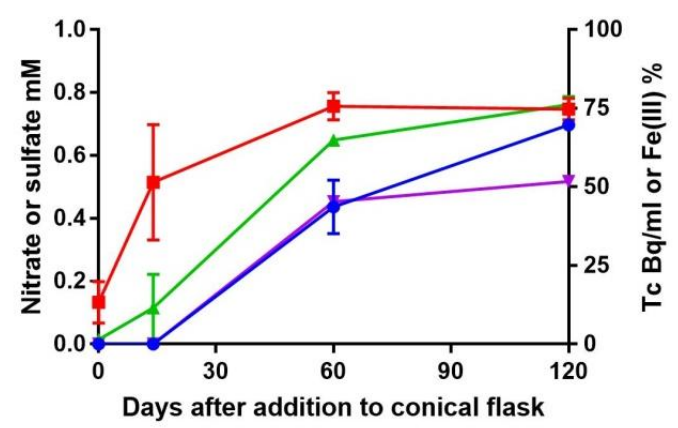

$\mp \mathrm{Tc}(\mathrm{Bq} / \mathrm{ml}) \rightarrow$ Sulfate $(\mathrm{mM})$

Figure S7. Oxidation of electron acceptors following reoxidation in air. Near-complete reoxidation of electron acceptors occurred in the experiments containing EHC and acetatelactate, but no $\mathrm{Tc}(\mathrm{VII})$ was released to solution with EHC, perhaps due to armouring of Tc(IV) by reoxidised Fe(III), or due to redox buffering by residual ZVI. It is noteworthy that at the end of the experiment there was $18 \mathrm{mM}$ of $0.5 \mathrm{~N} \mathrm{HCl}$-extractable total Fe in the EHC system compared to $2.6 \mathrm{mM}$ in the acetate/lactate experiment. Incomplete reoxidation of electron acceptors was observed with HRC and MRC, likely due to the presence of residual slow-release electron donor poising the system close to anaerobic conditions which prevented oxidation to $\mathrm{Fe}(\mathrm{III})$ and nitrate. 

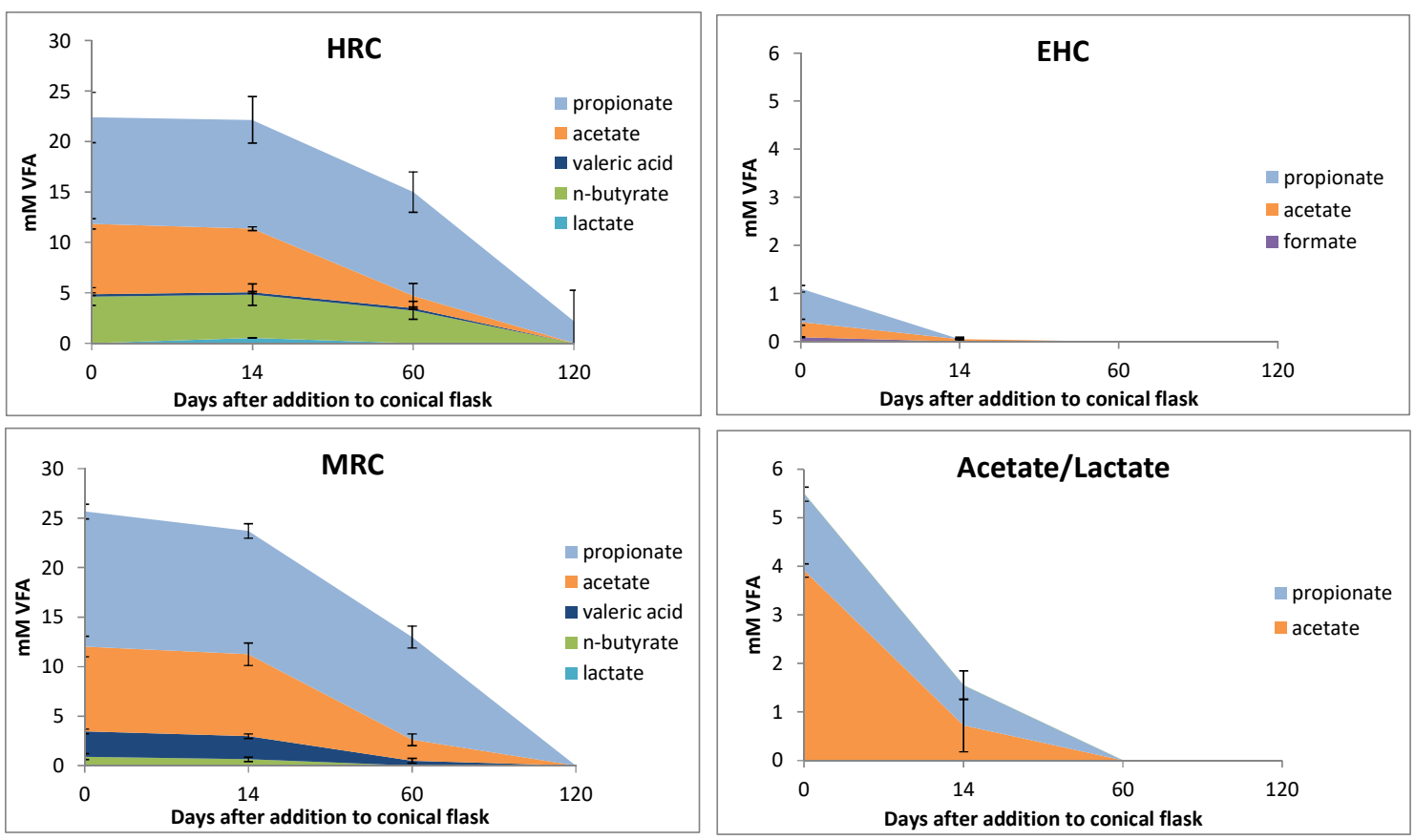

Figure S8. Changes in volatile fatty acids produced by biostimulation with slow release substrates and acetate/lactate during reoxidation conditions. Considerable quantities of VFAs remain present in the HRC and MRC systems even after 60 days exposure to highly oxidising conditions, which may offer a protective effect to $\mathrm{Tc}(\mathrm{IV})$ at lower concentrations. Note the differences in the y axis scales. 

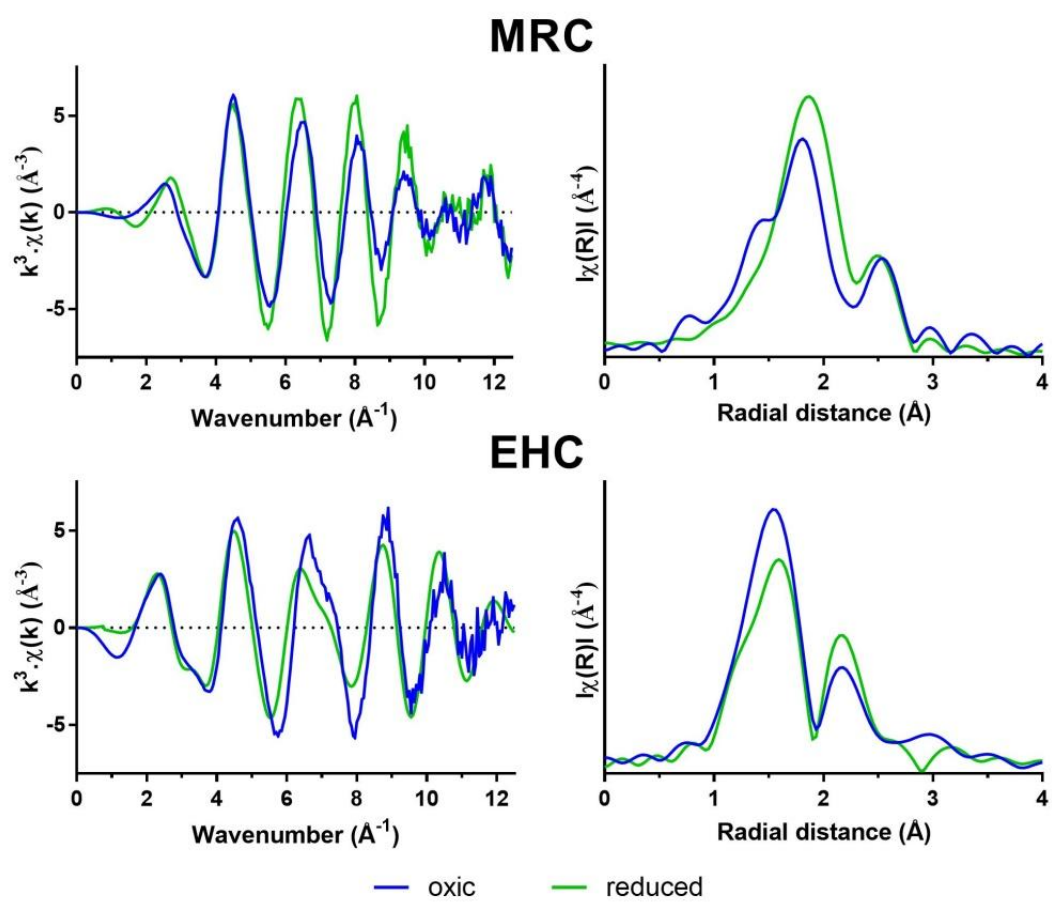

Figure S9. EXAFS of reoxidised samples (blue) plotted with reduced samples (green). 